\title{
A FUZZY DECISION-MAKING APPROACH FOR EVALUATION AND SELECTION OF THIRD PARTY REVERSE LOGISTICS PROVIDER USING FUZZY ARAS
}

\author{
Reza ROSTAMZADEH ${ }^{1^{*}}$, Ahmad ESMAEILI ${ }^{2}$, Henrikas SIVILEVIČIUS ${ }^{3}$, \\ Hossein Bodaghi Khajeh NOBARD ${ }^{4}$ \\ ${ }^{1}$ Dept of Management, Urmia Branch, Islamic Azad University, Urmia, Iran \\ ${ }^{2}$ Dept of Industrial Management, Allameh Tabataba'i University, Tehran, Iran \\ ${ }^{3}$ Transport and Logistics Competence Centre, Vilnius Gediminas Technical University, Lithuania \\ ${ }^{4}$ Dept of Marketing Management, Tabriz Branch, Islamic Azad University, Tabriz, Iran
}

Received 8 October 2018; revised 16 January 2019, 10 November 2019; accepted 3 February 2020

\begin{abstract}
Business environment is full of ups and down and this makes companies to develop different ways of using resources. By expanding life cycle of products, these ways can be cost effective and not harmful for environment. As Reverse Logistics (RL) uses a product after end of its life, it reduces pollution, therefore it has been considered as a part of sustainable development. The core goal of current research is developing a framework by which it evaluates Third Party RL Provider (3rdPRLP) using Multi-Criteria Decision-Making (MCDM) based on Fuzzy Additive Ratio ASsessment (FARAS). Thirty-seven criteria were identified, which are classified into seven main criteria. The main criteria were ranked as follows: product lifecycle position C1, RL process function C2, organizational performance C3, organizational role of RL C4, IT system and communication C5, general company consideration C6, geographical location C7. Market coverage, destination, financial considerations, integrated system, reclaim, efficiency and quality, and growth are each group's dominant sub-criteria. In addition, the current research helps the logistics managers to better understand the key attributes' complex relationships in the environment of decision-making.
\end{abstract}

Keywords: reverse logistics, sustainable development, 3rdPRLPs, MCDM, fuzzy sets, FARAS.

\section{Notations}
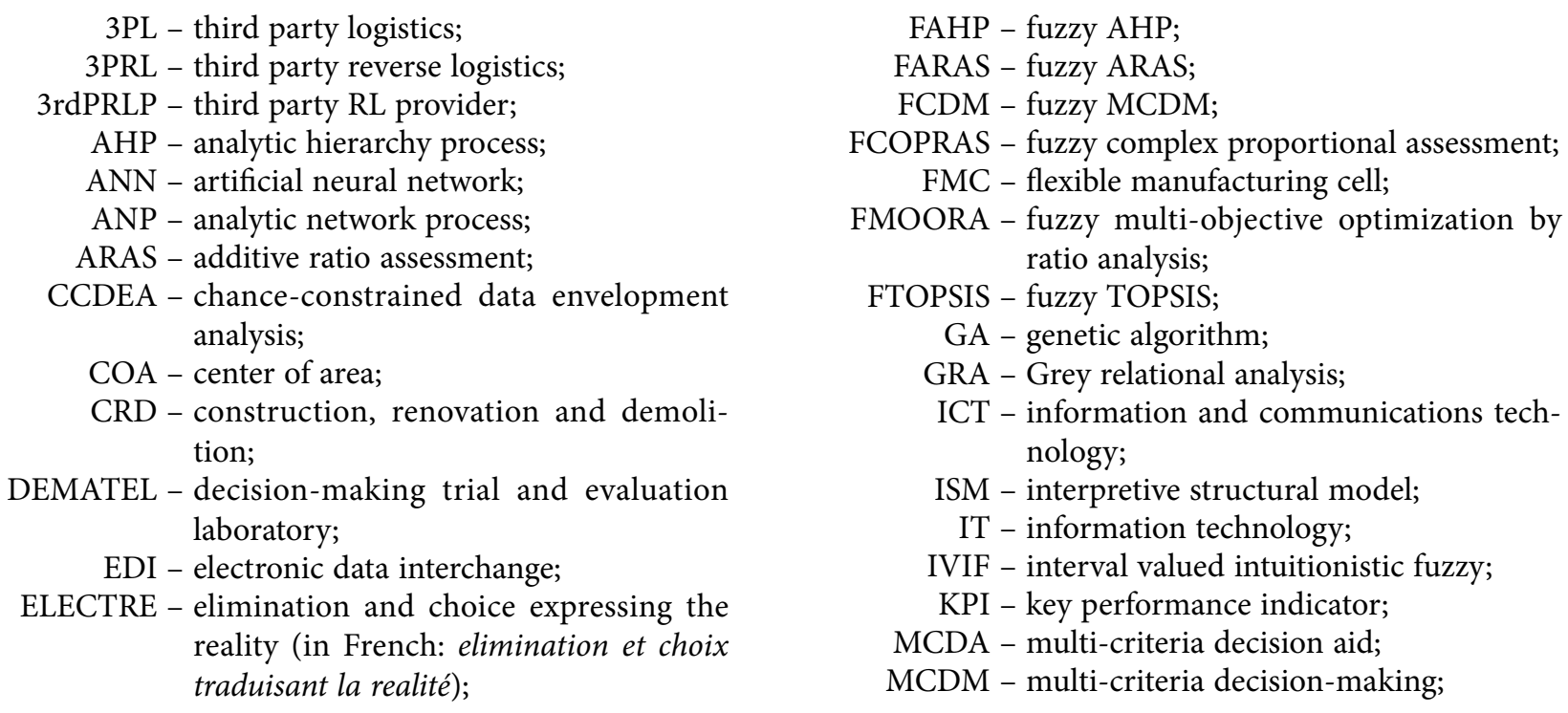

*Corresponding author. E-mail: rostamzadeh59@gmail.com 
MIGP - mixed integer goal programming;

MILP - mixed-integer linear programming;

MOPSO - multi-objective particle swarm optimization;

PROMETHEE - preference ranking organization method for enrichment evaluations;

PTFN - positive triangular fuzzy number;

QFD - quality function deployment;

RFID - radio-frequency identification;

$\mathrm{RL}$ - reverse logistics;

SERVQUAL - service quality;

SWARA - step-wise weight assessment ratio analysis;

SWOT - strengths, weaknesses, opportunities, and threats;

TFT LCD - thin film transistor liquid crystal display;

TOPSIS - technique for order preference by similarity to ideal solution;

VIKOR - multi-criteria optimization and compromise solution (in Serbian: višekriterijumska optimizacija i kompromisno rešenje).

\section{Introduction}

Corporate social responsibility, concerns about environment, and legislation are key reasons to why RL has become businesses' essential part. RL is the process of planning, implementing, and controlling the cost effective, efficient flow of raw materials, in-process inventory, finished goods and related information from the point of consumption to the point of origin for the purpose of recapturing value or proper disposal (Jayaraman et al. 2003).

A traditional forward supply chain involves the acquisition of raw material, production, and distribution of materials and products to end consumers, while RL involves the collection, inspection, disassembly, reprocessing, redistribution and reuse of used products, and the disposal of associated wastes. A closed-loop supply chain integrates and coordinates the forward and RL activities (Guide et al. 2003). Green supply chains have emerged as a result of an increase in issues related to environment. Green supply chains and RL and/or closed-loop supply chains differ from each other in that green supply chains focus on issues related to environment, while RL and closed-loop supply chains account for the economic benefits of options of product recovery (Bei, Linyan 2005; Bazan et al. 2016). Supply chain loop consists of important activities of forward logistics functions, but activities and functions of RL are necessary to fully close this loop. Because most companies are not very experienced with functions of RL, they may have difficulty in managing these RL functions (Bai, Sarkis 2013). RL channels for most product supply chains are relatively immature. Lack of development causes difficulty in disassembly, remanufacturing, and other environmentally oriented extended responsibility activities of producer dependent on RL (Subramoniam et al. 2013). RL environment grows uncertainty because of lack of development (Bai, Sarkis 2013).
Because of limitations in financial resources, many manufacturers have also understood that their logistics field is not competent, so they have attempted to buy logistics functions and services from third party providers of service. When noncore activities and processes are outsourced, focusing on core manufacturing activities becomes possible, while, at the same time, 3PL providers are competent in specific logistics, and logistics processes management by them becomes more efficient than having them managed by customers (Bottani, Rizzi 2006). Selection of partner of RL is a necessary part of return management. Because of many countries' environmental regulations, which require recycling or remanufacturing of used products, some firms are also made to deal with product returns (Agrawal et al. 2016a). Govindan and Popiuc (2014) propose that businesses can benefit from these returns. On the other hand, remanufactured products compared to new products provided higher margins just for few firms (Stock et al. 2002). Life expectancy of all products is finite. When goods' useful life finishes, consumers usually dispose or discard those goods. Environmental concerns and laws force the manufacturer to repossess or recall goods that breakdown or their life cycle finishes.

Because of limitations in resources, most companies are not succeeded in effective RL plan implementation or controlling networks, which are not complicated. The majority of the infrastructure for RL functions management is managed through a third party relationship. That is, municipal organizations, waste processors, or scrap yards are mostly involved with the recycling and reclamation process for materials that are flowing back into the system of forward logistics. But, regulatory and consumer pressures have caused organizations to re-evaluate their own RL infrastructure development (Bai, Sarkis 2013). Different literature studies have discussed that 3PL selection is a multi-objective decision because it requires taking into account several criteria. In addition, many firms are involved in these studies by which the importance of this decision is demonstrated. MCDM methods were applied in previous work individually or hybrid along with fuzzy sets in 3PRLs selection including; AHP (Fernandez, Kekale 2008), FAHP (Zhang, Feng 2007) AHP and FAHP (Kannan et al. 2009; Rajesh et al. 2009), FAHP and ANN (Efendigil et al. 2008), FAHP and fuzzy Delphi (Cheng et al. 2008), fuzzy Delphi and AHP (Bouzon et al. 2016), TOPSIS (Bottani, Rizzi 2006), AHP and FTOPSIS (Senthil et al. 2014), FAHP and FTOPSIS (Büyüközkan et al. 2008), ANP (Cheng, Lee 2010), ISM and FTOPSIS, VIKOR (Haji Vahabzadeh et al. 2015; Rostamzadeh et al. 2014b); VIKOR and FAHP (Rostamzadeh et al. 2014a; Prakash, Barua 2016a), DEMATEL, ELECTRE (De Almeida 2007), GRA and AHP (Khodaverdi, Hashemi 2015) and QFD. Further research using ARAS method with various variations can be found in the literature. Nguyen et al. (2016) developed an integrated MCDM model for conveyor equipment evaluation and selection in an FMC based on a FAHP and FARAS in 
the presence of vagueness. Zavadskas et al. (2017) presented an integrated group fuzzy multi-criteria model in case of facilities management strategy selection. They stated that the developed model is versatile in application and applies for various problems where the experts' knowledge is necessary for decision-making. Ecer (2018) has integrated FAHP and ARAS to evaluate banking service, which is claimed to deliver proper results under fuzzy environments. Büyüközkan and Göçer (2018) proposed an extension of ARAS methodology under IVIF environment for digital supply chain. The proposed framework integrates for the first time the IVIF sets, AHP and ARAS under a group decision-making environment. IVIF AHP is used to evaluate criteria weights and IVIF ARAS methodology is used for the alternative assessment procedure. The paper also included the analyses for the selection of a suitable supplier in a real case study from Turkey.

Fuzzy set theory and principles of knowledge management can be used to reduce selection measures' uncertainty. Without understanding this process very well, 3PRLs provider's conceptualization won't be clear and developing effective management frameworks won't be achieved. Application of the methodology and its managerial implications are this research's novel contributions. As far as we know, previously there hasn't been any research regarding 3rdPRLPs using ARAS. We have two goals in this paper. First, a framework is outlined for 3PRL's evaluation. Then, a method is developed in fuzzy environment as we have not come across any application of this technique in assessment of 3rdPRLPs.

The rest of this paper is organized as follows: RL related literature, specifically proposed criteria and 3rdPRLPs is discussed in Section 1. Proposed framework for evaluation of 3rdPRLPs using ARAS method developed in fuzzy environment is presented in Section 2. Section 3 discusses the application of the proposed framework for 3rdPRLPs selection in a real case environment. Finally, future work and conclusions are presented in the last section.

\section{Literature review}

As Aguezzoul (2014) investigated, 3PL's performance measurement is done through different techniques, which can be classified on 5 categories:

- hybrid methods;

- mathematical programming;

- artificial intelligence;

- statistical approaches;

- MCDM techniques.

3PRLs have been studied through different methods. In this study our focus is only on current MCDM's application in 3PRLs.

\subsection{Reverse logistics}

According to Rogers and Tibben-Lembke (2001), RL is defined " $[\ldots]$ as the process of controlling, implementing, and planning the cost effective and efficient flow of related information, process inventory, raw materials, and finished goods from the point of consumption to the point of origin for the purpose of proper disposal or recapturing value [...]". Fisk and Chandran (1975) study was one of the first studies by which product recall was investigated. They looked at traceability mechanisms for both non-durable and durable goods in an attempt to efficiently track the defective and hazardous products, but in their study no strategies of reverse distribution was developed. An empirical study was conducted by Murphy (1986) to obtain information concerning warehousing and transportation issues in a procedure of product recall. In their study no model was provided which would reduce costs of reverse distribution and no strategies of reverse distribution was developed. Strategies, which are related to the many "Rs" of environmental issues are introduced by corporations such as reuse, recovery, reclamation, reduction, recycling, and remanufacturing (Giuntini, Andel 1995a, 1995b, 1995c). Tate (1996) gives a picture of the most important successful logistic partnership elements, and some criteria of selection could be deduced from him. Sink and Langley (1997) only represent the selection step's main phases, but do not formalize a methodology, which is quantitatively structured to perform the selection step. Indeed, more than analysing the selection step's details, their work's major goal is to give a structured framework for the buying process as a whole. Quantitative methods regarding RL is elaborated by Fleischmann et al. (1997). In their study, the field is subdivided into three main areas as production planning, inventory control, and distribution planning. For this, they pointed out the areas in need for research in the future, reviewed the models of mathematics proposed in the literature, and discussed emerging reuse efforts implications.

There was a review on RL's literature by Carter and Ellram (1998). Their study suggested some critical factors in the process of RL. Menon et al. (1998), for instance, examine two main criteria for selecting service provider of 3PL, but their study mainly focuses on the way that a firm's external environment and competitiveness impact these criteria. Amini et al. (2005) designed an operation of RL for short cycle time repair services. Specifically they discussed repair services. They also studied the competitive value of activities of service management and the importance of the supporting role of effective RL operations for the profitable and successful execution of activities of repair service. In addition, the manuscript presents a case study of a major international medical diagnostics manufacturer to illustrate how an RL operation for a repair service supply chain was designed for both effectiveness and profitability by achieving a rapid cycle time goal for repair service while minimizing total capital and operational costs. Govindan and Popiuc (2014) defined an analytical model used to explore the implications of recycling on the RL from an efficiency perspective for all participants in the process of personal computers industry. The cases considered for analysis are the two- and threeechelon supply chains, where we first look at the decen- 
tralized reverse setting followed by the coordinated setting through implementation of revenue sharing contract. The results show that performance measures and total supply chain profits improve through coordination with revenue sharing con- tracts on both two- and three-echelon RL. Govindan and Soleimani (2017) provided a review on RL and closed-loop supply chains, mainly focused on publication from Journal of Cleaner Production. They categorized, and evaluated the related papers in order to provide a systematic view of past work and an appropriate vision for future study. A total of 83 accepted online papers up to 31 December 2014 have been selected and reviewed. Papers analysed based on their content and the appropriate developed categories. The results clarify the main trends on the topic and the evaluations reveal some suggested opportunities for new directions of research for the journal.

Trochu et al. (2018) presented RL network redesign under uncertainty for wood waste in the CRD industry. The main objective is to determine the location and the capacities of the sorting facilities to ensure compliance with the new regulation and prevent the wood from being massively landfilled. We formulated the problem as a MILP model to minimize the total cost of the wood recycling process collected from CRD sites. The main contribution lies in the consideration of important uncertain factors such as supply sources locations, the available quantity of recycled wood at the collection sites, and the various quality grades of the collected wood. However, in practice, the decision makers will have to choose a unique network configuration for the coming years that will efficiently handle various supply sources locations, waste collected quantities, and quality of the building materials.

\subsection{Application of MCDM in 3rdPRLPs}

Bottani and Rizzi (2006) presented a multi-attribute approach for the selection and ranking of the most suitable 3PL service provider using FTOPSIS. From the application of the methodology to a real case, the approach proposed emerges as an appropriate tool, which makes it possible to easily and effectively rank alternatives. Conversely the most critical issue pointed out by the real case application is the preliminary "request of information" phase, which has to be given critical attention. So et al. (2006) evaluated the service quality of 3PL service providers using the AHP. In order to measure 3PL service quality, we utilized the five generic dimensions of SERVQUAL. The results indicated that responsiveness (the willingness to help customers and provide prompt service) out of the five service quality dimensions is considered as the most important dimension perceived by 3PL customers. Göl and Çatay (2007) highlighted the efforts of a leading Turkish automotive company to restructure its supply chain for export parts. The paper presents hand-on experiences of a pilot project conducted at Tofaş-Fiat automotive company to redesign its logistics operations and to select a global logistics service provider, using an AHP. Totally 28 criteria were proposed for selection of 3PL. Even though the paper providing an insight into automotive industry, but it is not explained how the criteria were gathered. Further, there is no any discussion about the priority of the multicriteria and sub-criteria. De Almeida (2007) proposed a multi-criteria model for 3PL selection in Brazil based on utility function and ELECTRE method. The utility function is introduced to incorporate the uncertainty evaluation of criteria while ELECTRE tool determines the final selection of 3PL. The evaluating criteria considered are: cost, delivery time, and dependability. Aguezzoul (2007) presented literature review on evaluation criteria and various approaches used in selection of 3rdPRLPs. This paper identified 11 criteria and 4 evaluation methods namely MCDM, statistical, mathematical programming and soft computing. Fernandez and Kekale (2008) used Delphi and AHP method for decision-making of RL under multiple conflicting priorities. The methodology explained here will eventually produce the most important variables, but only as seen from the interviewees' viewpoint.

Cheng and Lee (2010) investigated on outsourcing RL of high-tech manufacturing firms by using a systematic decision-making approach: TFT LCD sector in Taiwan. They used the ANP not only to investigate the relative importance of RL service requirements, but also to select an appropriate 3PL. Results of this study significantly contribute to the efforts of 3PLs in evaluating whether they comply with potential customer requirements based on their service capabilities. Despite its contributions, it focuses mainly on high-tech manufacturers in Taiwan, predominantly from the TFT LCD sector. Besides, this study adopts the key informant approach to collect data. Even though informants sampled were familiar with the service requirements of RL, however, this approach only records what is pertinent to decision-making rather than how a selection is considered in the final decision. Bai and Sarkis (2013) introduced a RL flexibility framework. The framework is separated into operational and strategic flexibilities. Operational flexibility includes a variety of dimensions such as product and volume flexibility across various RL operational functions. They have also included strategic flexibility categorized into network and organizational design flexibility dimensions. Additional sub-dimensions are also included in the framework. The framework is useful for practical managerial decisionmaking purposes such as process improvement or programmatic evaluation. The framework is also useful as a theoretical construct for RL empirical research. Senthil et al. (2014) proposed robust MCDM approach for evaluation and selection of 3rdPRLPs for plastic industry and used AHP and FTOPSIS method. Apart from this in this paper, sensitivity analysis was carried out. Haji Vahabzadeh et al. (2015) proposed green decision-making model in RL using fuzzy VIKOR method. First, the significant factors in environmental sound practices together with the main processes and recovery options in RL are identified. Second, the influences of each green environmental factor on each RL recovery option are analysed and ranked. The final results illustrate that, intriguingly, disposing of the 
returns has the lowest negative impact on the environment; thereby the best recovery option, while reselling of the returns was perceived as the worst recovery option. Khodaverdi and Hashemi (2015) utilized a combination of AHP and GRA for the evaluation of 3PRLs service providers based on financial and environmental performance. This paper uses grey numbers for expressing ambiguity of the real world data and subjectivity of decision makers' assessments and presents a grey possibility degree for ranking 3rdPRLPs. Guarnieri et al. (2015) identified the main criteria and proposed the systematic methods that can be used in order to select the most appropriate 3rdPRLP based on MCDA approach.

Prakash and Barua (2016a) proposed a combined FAHP and VIKOR approach for evaluation and selection of 3PRPs using various criteria among the Indian electronics industry. RL operations known to be the most important criteria and geographical location obtained the lowest important. In addition, sensitivity analysis provided more insight to the cause of selection of appropriate 3PRLs for implementation of RL. Agrawal et al. (2016b) explored the various disposition alternatives and developed an approach for the selection of best disposition alternative using graph theory and matrix approach. A case of mobile manufacturing firm is discussed for the illustration of this approach. The firm has to select best disposition alternative among four identified alternatives such as returned products for repair or reuse and resell as new; or repair or refurbish and resell; or re- manufacture and sell; or recycle. The results show that firm must repair or reuse and resell the returned mobile phones as new in present business scenario in India. In addition, recycling must be preferred over remanufacturing of returned mobile phones. The study contributes to the limited literature available for the disposition decision-making in RL. However, these results may not be generalized because it is illustration of an approach for a firm. Govindan et al. (2016) proposed a fuzzy multi-objective optimization model for sustainable RL network design. To reflect all aspects of sustainability, they minimized the present value of costs, as well as environmental impacts, and optimize the social responsibility as objective functions of the model. In order to deal with uncertain parameters, fuzzy mathematical programming is used, and to obtain solutions on Pareto front, a customized MOPSO algorithm is applied. The results reveal that the suggested MOPSO algorithm overtakes epsilon-constraint method from the aspects of quality of the solutions as well as computational time. An integrated intuitionistic FAHP and SWOT method for outsourcing RL proposed by Tavana et al. (2016). First, the relevant criteria and sub-criteria are identified using a SWOT analysis. Then, Intuitionistic FAHP is used to evaluate the relative importance weights among the criteria and the corresponding sub-criteria. These relative weights are implemented in a novel extension of Mikhailov's fuzzy preference programming method to produce local weights for all criteria and sub-criteria. Finally, these local weights are used to assign a global weight to each sub-criterion and create a ranking. The results showed that the most important priority is to focus on the core business, while reducing costs constitutes one of its least important priorities. Senthil et al. (2018) analysed and prioritized of risks in a RL network using AHP FTOPSIS and PROMETHEE methods. The results indicate that managing inventory has a significant impact on RL. It was observed that social concern with respect to protecting the environment in general is based on the cooperation of customers. Table 1 shows the previous researches.

\subsection{Proposed criteria for 3PRLs selection}

\section{Product lifecycle position}

Lifestyle is influenced through position of product. In the concept of life cycle of product, a product's life in the market is considered, with respect to measures of commercial/ business costs and sales. Product stage identification more than science is considered as an art. On the other hand, finding patterns in some of the features of general product at each stage is possible. It is very difficult to identify stages of product when the product is in transition. Marketing management would have difficulty in accurate measurement of position of a product in its life cycle. Neither a rise in sales per se necessarily shows growth, nor a fall in sales per se typify decline and some products may not experience a decline. The four main stages of a product's life cycle are:

- market introduction;

- growth;

- maturity and saturation;

- decline.

\section{$R L$ process functions}

In supply chain's forward movement, reverse flow plays a critical role. By estimating process flow of a supply chain of a consumer, one can induce that reverse flows comprehensively recover the expense of product. Product movement from one point to the other also is considered by RL. It is changed from the point of consumption to the point of origin. Some of the main function are: collection, packing, storage, sorting, transitional process, delivery.

\section{Organizational performance criteria}

Measuring performance is a vital part of monitoring an organization's progress. It comprises measuring the actual performance outcomes or results of an organization against its intended goals. Consist of traditional strategic organizational metrics such as (Kleindorfer, Partovi 1990; Sarkis 1998; Meade, Sarkis 2002):

$$
\begin{aligned}
& \text { - time; } \\
& \text { - cost; } \\
& \text { - quality; } \\
& \text { - flexibility; } \\
& \text { - efficiency; } \\
& \text { - effectiveness. }
\end{aligned}
$$


Table 1. Summary of pervious researches

\begin{tabular}{|c|c|c|c|}
\hline Author(s) & RLs criteria & $\begin{array}{l}\text { Techniques } \\
\text { and methods }\end{array}$ & Research objectives \\
\hline $\begin{array}{l}\text { Sink et al. } \\
(1996)\end{array}$ & $\begin{array}{l}\text { transportation, freight bill payment/audit distribution, warehousing, } \\
\text { inventory management, packaging, RL }\end{array}$ & survey & $\begin{array}{l}\text { buyer observations of the } \\
\text { US 3PL market }\end{array}$ \\
\hline $\begin{array}{l}\text { Blumberg } \\
(1999)\end{array}$ & $\begin{array}{l}\text { storage and warehousing collection and sorting substitution } \\
\text { transportation and distribution disposal depot repair and } \\
\text { remanufacturing recertification }\end{array}$ & survey & $\begin{array}{l}\text { strategic examination } \\
\text { of RL and repair } \\
\text { service requirements, } \\
\text { needs, market size, and } \\
\text { opportunities }\end{array}$ \\
\hline $\begin{array}{l}\text { Meade, } \\
\text { Sarkis } \\
(2002)\end{array}$ & $\begin{array}{l}\text { product lifecycle position, organizational performance criteria, RL process } \\
\text { function, organizational role of RL }\end{array}$ & ANP & $\begin{array}{l}\text { a conceptual model for } \\
\text { selecting and evaluating } \\
\text { 3PLP }\end{array}$ \\
\hline $\begin{array}{l}\text { Ravi et al. } \\
(2005)\end{array}$ & $\begin{array}{l}\text { customer perspective: convenience, customer service, green products, } \\
\text { customer satisfaction; internal business perspective: IT, product recovery } \\
\text { options, commitment by top management, new technologies; innovation } \\
\text { and learning perspective: competitiveness, mentoring of suppliers, } \\
\text { formation of strategic alliances, knowledge management; financial } \\
\text { perspective, waste reduction, cost saving, recapturing value }\end{array}$ & $\begin{array}{l}\text { ANP and } \\
\text { balanced } \\
\text { scorecard }\end{array}$ & $\begin{array}{l}\text { analysing the alternatives } \\
\text { to execute RL programs }\end{array}$ \\
\hline $\begin{array}{l}\text { Bottani, } \\
\text { Rizzi (2006) }\end{array}$ & $\begin{array}{l}\text { breadth of service, business experience, characterization of service, } \\
\text { compatibility, financial stability, flexibility of service, performance, price, } \\
\text { physical equipment and information systems, quality, strategic attitude, } \\
\text { trust and fairness }\end{array}$ & FTOPSIS & $\begin{array}{l}\text { to present a multi- } \\
\text { attribute approach for } \\
\text { the selection and ranking } \\
\text { of the most suitable 3PL } \\
\text { service provider }\end{array}$ \\
\hline $\begin{array}{l}\text { So et al. } \\
(2006)\end{array}$ & tangibles, reliability, responsiveness, assurance and empathy & AHP & $\begin{array}{l}\text { evaluation of the service } \\
\text { quality internet shopping } \\
\text { mall in Korea }\end{array}$ \\
\hline $\begin{array}{l}\text { Göl, Çatay } \\
(2007)\end{array}$ & $\begin{array}{l}\text { general company consideration (price, financial considerations, } \\
\text { experience in the same industry, location, asset ownership, international } \\
\text { scope, growth forecasts, yearly efficiency), capabilities (optimization } \\
\text { capabilities, creative management, customer service, supply chain vision, } \\
\text { responsiveness), quality (service quality, continuous improvement, KPI } \\
\text { measurement and reporting), client relationship (availability of top } \\
\text { management, cultural fit, service cancellation, reputation) and labour } \\
\text { relations (human resource policies, availability of qualified talent) }\end{array}$ & AHP & $\begin{array}{l}\text { selecting } 3 \mathrm{PL} \text { in } \\
\text { automotive in Turkey }\end{array}$ \\
\hline \begin{tabular}{l|} 
Zhang, \\
Feng (2007)
\end{tabular} & strength, union, services, experience, price & FAHP & $\begin{array}{l}\text { selection process of } \mathrm{RL} \\
\text { provider }\end{array}$ \\
\hline $\begin{array}{l}\text { De Almeida } \\
(2007)\end{array}$ & cost, delivery time, and dependability & $\begin{array}{l}\text { utility } \\
\text { function and } \\
\text { ELECTRE }\end{array}$ & $\begin{array}{l}\text { outsourcing contracts } \\
\text { selection }\end{array}$ \\
\hline $\begin{array}{l}\text { Pati et al. } \\
(2008)\end{array}$ & RL cost, non-relevant wastepaper target, waste paper recovery target & MIGP & $\begin{array}{l}\text { manage the paper } \\
\text { recycling in logistics } \\
\text { systems }\end{array}$ \\
\hline $\begin{array}{l}\text { Efendigil } \\
\text { et al. }(2008)\end{array}$ & $\begin{array}{l}\text { on time delivery ratio, confirmed fill rate. service quality level, unit } \\
\text { operation cost, capacity usage ratio, total order cycle time, system } \\
\text { flexibility index, integration level index, increment in market share, } \\
\text { research and development ratio, environmental expenditures, customer } \\
\text { satisfaction index, alternative priority weight }\end{array}$ & $\begin{array}{l}\text { FAHP and } \\
\text { ANN }\end{array}$ & select the best 3rdPRLPs \\
\hline $\begin{array}{l}\text { Min, Ko } \\
(2008)\end{array}$ & $\begin{array}{l}\text { fixed cost of maintaining a warehouse, cost of establishing a warehouse, } \\
\text { fixed cost of expanding a warehouse, variable cost of expanding a } \\
\text { warehouse, fixed cost of maintaining a repair facility, cost of establishing } \\
\text { a repair facility fixed cost of expanding a repair facility, variable cost of } \\
\text { expanding a repair facility, savings from the use of an existing warehouse } \\
\text { as a repair facility, production capacity of the client plant, maximum } \\
\text { capacity per warehouse, maximum capacity per repair center, maximum } \\
\text { capacity of expansion per warehouse, maximum capacity of expansion } \\
\text { per repair facility, maximum period of expansion, demand forecasts for } \\
\text { each client' product (in units), return forecasts for each clients' product } \\
\text { (in units). }\end{array}$ & $\begin{array}{l}\text { MIGP and } \\
\text { GA }\end{array}$ & $\begin{array}{l}\text { selecting the most } \\
\text { appropriate } 3 \text { rdPRLP }\end{array}$ \\
\hline $\begin{array}{l}\text { Fernandez, } \\
\text { Kekale } \\
(2008)\end{array}$ & $\begin{array}{l}\text { internal (companies), external (government, customer, competitor, } \\
\text { suppliers) }\end{array}$ & $\begin{array}{l}\text { AHP and } \\
\text { Delphi } \\
\text { method }\end{array}$ & $\begin{array}{l}\text { a conceptual decision- } \\
\text { making model under } \\
\text { multiple conflicting } \\
\text { criteria: the case of RL }\end{array}$ \\
\hline
\end{tabular}


Continue of Table 1

\begin{tabular}{|c|c|c|c|}
\hline Author(s) & RLs criteria & $\begin{array}{l}\text { Techniques } \\
\text { and methods }\end{array}$ & Research objectives \\
\hline $\begin{array}{l}\text { Rajesh et al. } \\
(2009)\end{array}$ & cost, financial viability, risk mitigation, it capability, on-time delivery & $\begin{array}{l}\text { AHP and } \\
\text { FTOPSIS }\end{array}$ & $\begin{array}{l}\text { an analytic model } \\
\text { for selection of and } \\
\text { allocation among 3PL } \\
\text { service providers }\end{array}$ \\
\hline $\begin{array}{l}\text { Kannan } \\
(2009)\end{array}$ & $\begin{array}{l}\text { quality, cost, time, flexibility, collection, packing, storage, storing, } \\
\text { transitional, process, delivery, reclaim, recycle, remanufacture, reuse, } \\
\text { disposal, warehouse management }\end{array}$ & $\begin{array}{l}\text { AHP and } \\
\text { FAHP }\end{array}$ & selection of 3rdPRLPs \\
\hline $\begin{array}{l}\text { Kannan } \\
\text { et al. (2009) }\end{array}$ & $\begin{array}{l}\text { quality, delivery, RL cost, rejection rate, technical/engineering capability, } \\
\text { inability to meet future requirement, willingness and attitude }\end{array}$ & $\begin{array}{l}\text { ISM and } \\
\text { FTOPSIS }\end{array}$ & $\begin{array}{l}\text { the selection of } \\
\text { 3rdPRLPs }\end{array}$ \\
\hline $\begin{array}{l}\text { Cheng, Lee } \\
(2010)\end{array}$ & $\begin{array}{l}\text { warehouse management, transportation management, it management, } \\
\text { value added service }\end{array}$ & ANP & $\begin{array}{l}\text { outsourcing RL of high- } \\
\text { tech manufacturing } \\
\text { firms by using a } \\
\text { systematic decision- } \\
\text { making approach }\end{array}$ \\
\hline $\begin{array}{l}\text { Azadi, Saen } \\
(2011)\end{array}$ & $\begin{array}{l}\text { total cost of shipments, revenue from the sale of recyclable, service quality } \\
\text { experience rating, service quality credence rating }\end{array}$ & $\begin{array}{l}\text { new CCDEA } \\
\text { approach }\end{array}$ & $\begin{array}{l}\text { selecting the most } \\
\text { appropriate } 3 \mathrm{rdPRLPs}\end{array}$ \\
\hline $\begin{array}{l}\text { Falsini et al. } \\
(2012)\end{array}$ & $\begin{array}{l}\text { quality and reliability, speed of service, flexibility, costs, equipment, } \\
\text { operators' safety, environmental safeguard }\end{array}$ & $\begin{array}{l}\text { AHP, DEA } \\
\text { and linear } \\
\text { programming }\end{array}$ & $\begin{array}{l}\text { 3PL service provider } \\
\text { selection among the } \\
\text { industry and defence } \\
\text { perishable products, } \\
\text { consumers goods in Italy }\end{array}$ \\
\hline $\begin{array}{l}\text { Perçin, Min } \\
(2013)\end{array}$ & $\begin{array}{l}\text { customer needs: cost, timeliness, service quality, flexibility, reputations. } \\
\text { technical requirements: industry experience (years) cycle time (day) } \\
\text { delivery service failures, capacity utilization, technological integration, } \\
\text { financial growth rate, managerial staff level, geographical proximity }\end{array}$ & $\begin{array}{l}\text { QFD and } \\
\text { fuzzy linear } \\
\text { regression }\end{array}$ & $\begin{array}{l}\text { selecting of 3PL } \\
\text { service provider } \\
\text { among the automobile } \\
\text { manufacturing company } \\
\text { in Turkey }\end{array}$ \\
\hline $\begin{array}{l}\text { Bai, Sarkis } \\
(2013)\end{array}$ & collection, separation/ inspection, storage, disassembly, compaction & $\begin{array}{l}\text { neighbour- } \\
\text { hood rough } \\
\text { set approach }\end{array}$ & $\begin{array}{l}\text { a framework for RL } \\
\text { flexibility }\end{array}$ \\
\hline $\begin{array}{l}\text { Subramo- } \\
\text { niam et al. } \\
(2013)\end{array}$ & $\begin{array}{l}\text { design for remanufacturing, financial impact of remanufacturing, } \\
\text { protection of intellectual, property of product specifications, core } \\
\text { management, brand erosion, green perception, integrated organizational, } \\
\text { alignment, government regulations }\end{array}$ & AHP & $\begin{array}{l}\text { remanufacturing } \\
\text { decision-making } \\
\text { framework }\end{array}$ \\
\hline $\begin{array}{l}\text { Senthil } \\
\text { et al. (2014) }\end{array}$ & $\begin{array}{l}\text { organizational performance criteria, RL process functions, organizational } \\
\text { role of RL, resources capacity, quality of service, enterprise alliance, } \\
\text { location, experience, communication systems }\end{array}$ & $\begin{array}{l}\text { AHP and } \\
\text { FTOPSIS }\end{array}$ & $\begin{array}{l}\text { a hybrid MCDM } \\
\text { methodology for } \\
\text { contractor evaluation } \\
\text { and selection in third } \\
\text { party RL }\end{array}$ \\
\hline $\begin{array}{l}\text { Khodaverdi, } \\
\text { Hashemi } \\
(2015)\end{array}$ & $\begin{array}{l}\text { IT management, delivery, RL costs, warehouse management, value added } \\
\text { services }\end{array}$ & $\begin{array}{l}\text { AHP and } \\
\text { GRA }\end{array}$ & $\begin{array}{l}\text { selecting a RL provider } \\
\text { in a closed-loop supply } \\
\text { chain }\end{array}$ \\
\hline $\begin{array}{l}\text { Guarnieri } \\
\text { et al. }(2015)\end{array}$ & $\begin{array}{l}\text { logistics, financial, capacity/ infrastructure, value added services to } \\
\text { customers, alliances with suppliers, environmental }\end{array}$ & MCDA & $\begin{array}{l}\text { evaluating 3rdPRLPs } \\
\text { in a multi-criteria } \\
\text { perspective: a Brazilian } \\
\text { case }\end{array}$ \\
\hline $\begin{array}{l}\text { Bouzon } \\
\text { et al. }(2015)\end{array}$ & $\begin{array}{l}\text { lack of personnel technical skills, lack of IT systems standards, lack of } \\
\text { latest technologies for recovering products, technology and the research } \\
\text { and development issues related to product recovery, difficulties with } \\
\text { supply chain members, limited forecasting and planning in reverse } \\
\text { activities, inconsistent quality of returned products, lack of appropriate } \\
\text { performance management system, lack of initial capital, lack of taxation } \\
\text { knowledge on returned products. lack of specific laws, lack of waste } \\
\text { management practices, lack of inter-ministerial communication, lack of } \\
\text { motivation laws, misuse of environmental regulations, extended producer } \\
\text { responsibility across countries, company policies against RL, perception } \\
\text { of a poorer quality product, low importance of RL relative to other issues, } \\
\text { low involvement of top management and strategic planning }\end{array}$ & $\begin{array}{l}\text { DEMATEL } \\
\text { and GRA }\end{array}$ & $\begin{array}{l}\text { evaluating barriers for } \\
\text { RL implementation } \\
\text { under a multiple } \\
\text { stakeholders' perspective } \\
\text { analysis }\end{array}$ \\
\hline $\begin{array}{l}\text { Agrawal } \\
\text { et al. } \\
(2016 \mathrm{a})\end{array}$ & reuse, repairing, remanufacturing, recycling and disposal & $\begin{array}{l}\text { graph theory } \\
\text { and matrix } \\
\text { approach }\end{array}$ & $\begin{array}{l}\text { disposition decisions } \\
\text { in RL }\end{array}$ \\
\hline
\end{tabular}


End of Table 1

\begin{tabular}{|c|c|c|c|}
\hline Author(s) & RLs criteria & $\begin{array}{l}\text { Techniques } \\
\text { and methods }\end{array}$ & Research objectives \\
\hline $\begin{array}{l}\text { Agrawal } \\
\text { et al. } \\
(2016 b)\end{array}$ & $\begin{array}{l}\text { balanced scored view (financial perspective, internal process perspective, } \\
\text { stakeholders perspective, learning and growth); environmental } \\
\text { perspective, social perspective }\end{array}$ & $\begin{array}{l}\text { balanced } \\
\text { scorecard } \\
\text { and graph } \\
\text { theoretic } \\
\text { approach }\end{array}$ & $\begin{array}{l}\text { outsourcing decisions } \\
\text { in RL }\end{array}$ \\
\hline $\begin{array}{l}\text { Tavana } \\
\text { et al. }(2016)\end{array}$ & $\begin{array}{l}\text { strength: focus on the main business, risk sharing, product quality, } \\
\text { enhanced return on investment, cost management, customer satisfaction; } \\
\text { weakness: hidden cost of outsourcing, given the full attorney to a third } \\
\text { party, organizational control, flexibility reduction, commitment and risk } \\
\text { coverage; opportunity: environmental compatibility, increasing market } \\
\text { share, standardization, proper relations among staffs, organizational } \\
\text { growth; threat: carry risk, stealing material and data, increasing inventory, } \\
\text { economic recession, tax risk }\end{array}$ & FAHP SWOT & $\begin{array}{l}\text { selection of the best } 3 P \\
\text { RLPs }\end{array}$ \\
\hline $\begin{array}{l}\text { Prakash, } \\
\text { Barua } \\
(2016 a)\end{array}$ & $\begin{array}{l}\text { firm performance (time, flexible capacity, convenience), resources capacity } \\
\text { (investment capacity, advanced components and equipment, warehousing } \\
\text { and storage), service delivery (service level, customized service, problems } \\
\text { resolution ability), RL operations (collection, sorting, warehousing, } \\
\text { intermediate process, transportation, repair, recycle, remanufacturing, } \\
\text { disposal), communication and IT system (integrated system, separate } \\
\text { and shared communication, RFID/EDI enabled system, information } \\
\text { security system), geographical location (destination and market coverage, } \\
\text { shipment, distribution), reputation and experience (image, shared benefits } \\
\text { and risks, structure, culture) }\end{array}$ & $\begin{array}{l}\text { FAHP and } \\
\text { VIKOR }\end{array}$ & $\begin{array}{l}\text { evaluation and selection } \\
\text { of 3rdPRLPs for Indian } \\
\text { electronics industry }\end{array}$ \\
\hline $\begin{array}{l}\text { Prakash, } \\
\text { Barua } \\
(2016 b)\end{array}$ & $\begin{array}{l}\text { capacity criteria, financial ability, IT system, service quality, RL activities, } \\
\text { geographical location, partner image and experience }\end{array}$ & $\begin{array}{l}\text { FAHP and } \\
\text { FTOPSIS }\end{array}$ & $\begin{array}{l}\text { an analysis of integrated } \\
\text { robust hybrid model for } \\
\text { 3rdPRLPs selection }\end{array}$ \\
\hline $\begin{array}{l}\text { Senthil } \\
\text { et al. }(2018)\end{array}$ & $\begin{array}{l}\text { environmental risk, inventory risk, data managing risk, time management } \\
\text { risk, managerial risk, cultural risk, quantity risk, outsourcing risk, } \\
\text { disruption/catastrophic risk }\end{array}$ & $\begin{array}{l}\text { AHP, } \\
\text { FTOPSIS and } \\
\text { PROMETHEE }\end{array}$ & $\begin{array}{l}\text { risks involved in RL } \\
\text { are prioritized using } \\
\text { hybrid MCDM in plastic } \\
\text { recycling firm }\end{array}$ \\
\hline
\end{tabular}

\section{Organizational role of $R L$}

A trader is allowed by RL to get products back from the consumer or send unsold products back to the manufacturer to be recycled, reassembled, sorted or taken apart; so, organizations should have their own RL implemented which minimizes their overall costs. RL can be valuable in increasing consumer preferences and maintainable practices, complexity of supply chain, and lifecycles of product, which have to be improved to maintain growth and productivity. Gains can include customer retention, costs reduction, increasing production speed by improving goals of service and meeting goals of sustainability. Returned/ used goods can give more value instead of wasting costs, time, and manpower of raw materials involved in the original supply chain. Customer loyalty and satisfaction can be improved by considering repairs of merchandise and goods, which have problems. The following criteria used for this purpose:

$$
\begin{aligned}
& \text { - reclaim; } \\
& \text { - recycle; } \\
& \text { - remanufacture; } \\
& \text { - reuse; } \\
& \text { - take back; } \\
& \text { - disposal. }
\end{aligned}
$$

\section{IT system and communication}

IT's extended term is ICT by which unified communications' role is stressed. There is no universal definition for ICT. Development of the applications, methods, and concepts involved in ICT is on daily basis. The ICT's broadness covers any product that will receive, transmit, manipulate, retrieve, or store information electronically. At any business' core there is the Information Systems. Factors such as outsourcing and globalization have led to increased demand for an effectual IT environment. The key to manage business activities of an enterprise in a smooth and effective way is a good server system. Management of Effectual IT system services can surely pave the way to competitive benefits. One can considerably reduce expenses related to operation, therefore, standardized IT equipment will be enabled and redundancy and waste will be eliminated. Enhanced IT functions can be enabled by IT management services because it increases data and system security. In addition, availability and efficiency of computer networks and peripherals are improved through efficient systems management services. Besides, they predict and correct the technical problems. The following criteria were used in this research:

- RFID communication;

- RFID/EDI enabled system;

- information security system. 


\section{General company consideration}

Almost all savvy business entrepreneurs and investors have to confront with the challenge of choosing the right type of business enterprise. Many factors are involved in choosing entity for a particular business. Any chosen business form may greatly influence business success. The chosen structure will influence the owner's control over the business, the way of keeping records of accounting, paying taxes, obtaining financing, and whether personal assets are at risk in the venture, also and many other aspects of the business. The following criteria were used:

- yearly efficiency;

- growth of forecasts;

- price;

- international scope;

- ownership asset;

- top management availability;

- experience in the same industry;

- financial considerations.

\section{Geographical location}

The practice of diversifying an investment portfolio across different geographic regions to reduce the overall risk and improve returns on the portfolio. Large companies employ strategies locating their operations in different countries or regions to reduce risks related to operations and business. Criteria included:

- destination;

- market coverage;

- shipment;

- distribution.

\section{Methodology}

This section describes the methodology was applied in this research. The proposed model is based on fuzzy sets theory and ARAS method, which will be discussed in continue.

\subsection{Fuzzy sets}

Fuzzy set theory first was introduced by Zadeh (1965) to map linguistic variables to numerical variables within decision-making processes. Later, it was manipulated to develop FMCDM methodology by Bellman and Zadeh (1970) to resolve the lack of precision in assigning importance weights of criteria and the ratings of alternatives against evaluation criteria. Because human minds work with a different logic and make decisions based on it, therefore, it is necessary to build and invent new logical and multivalued methods, which fuzzy logic is one of them. Some of the basic definition of fuzzy sets (Zadeh 1965; Zimmermann 1987, 1991; Kaufmann, Gupta 1991) presented as follows:

- Definition 1. (Fuzzy set). Let $X$ be the universe of discourse, $X=\left\{x_{1}, x_{1}, \ldots, x_{n}\right\}$. A fuzzy set $\tilde{A}$ of $X$ is a set of order pairs $\left\{\left(x_{1}, f_{\tilde{A}}\left(x_{1}\right)\right),\left(x_{2}, f_{\tilde{A}}\left(x_{2}\right)\right), \ldots\right.$, $\left.\left(x_{n}, f_{\tilde{A}}\left(x_{n}\right)\right)\right\}$, where $f_{\tilde{A}}: X \rightarrow[0,1]$ is the membership function of $A ; f_{\tilde{A}}\left(x_{i}\right)$ stands for the membership degree of $x_{i}$ in $\tilde{A}$. The larger $f_{\tilde{A}}\left(x_{i}\right)$, the stronger the grade of membership for $x$ in $\tilde{A}$;

- Definition 2. (Fuzzy number). A fuzzy set $\tilde{A}$ of the universe of discourse $X$ is convex if and only if for all $x_{1}, x_{2}$ in $X, \mu_{\tilde{A}}\left(\lambda \cdot x_{1}+(1-\lambda) \cdot x_{2}\right) \geq \min \left(\mu_{\tilde{A}}\left(x_{1}\right), \mu_{\tilde{A}}\left(x_{2}\right)\right)$, where $\lambda \in[0,1]$. It is called a normal fuzzy set implying that $\exists x_{i} \in X, \mu_{\tilde{A}}\left(x_{i}\right)=1$. For simplicity without loss of generality, trapezoidal fuzzy numbers are preferred over triangular fuzzy numbers for representing the linguistic variables in this study. A PTFN can be defined as $\left\{\left(n_{1}, n_{2}, n_{3}, n_{4}\right) \mid n_{1}, n_{2}, n_{3}, n_{4} \in R ; n_{1} \leq n_{2} \leq n_{3} \leq n_{4}\right\}$, which respectively, denotes the smallest possible, most promising, and largest possible values and the membership function is defined using Equation (1) and it is shown in Figure 1. A PTFN can encompass more uncertainty than the triangular fuzzy number (Shemshadi et al. 2011):

$$
(x \mid \tilde{M})= \begin{cases}\frac{x-n_{1}}{n_{2}-n_{1}}, & x \in\left[n_{2}, n_{3}\right] ; \\ \frac{n_{4}-x}{n_{4}-n_{3}}, & x \in\left[n_{2}, n_{3}\right] ; \\ 0, & \text { otherwise; }\end{cases}
$$

- Definition 3. Given any two PTFN, $\tilde{a}=\left(a_{1}, a_{2}, a_{3}, a_{4}\right)$, $\tilde{b}=\left(b_{1}, b_{2}, b_{3}, b_{4}\right)$ and a positive real number $r$, some main operations of fuzzy numbers $\tilde{A}$ and $\tilde{B}$ can be expressed as follows:

$$
\begin{aligned}
& \tilde{A} \oplus \tilde{B}=\left(a_{1}+b_{1}, a_{2}+b_{2}, a_{3}+b_{3}, a_{4}+b_{4}\right) ; \\
& \tilde{A} \ominus \tilde{B}=\left(a_{1}-b_{1}, a_{2}-b_{2}, a_{3}-b_{3}, a_{4}-b_{4}\right) ; \\
& \tilde{A} \otimes \tilde{B} \cong\left(a_{1} \cdot b_{1}, a_{2} \cdot b_{2}, a_{3} \cdot b_{3}, a_{4} \cdot b_{4}\right) ; \\
& \tilde{A} \otimes r \cong\left(a_{1} \cdot r, a_{2} \cdot r, a_{3} \cdot r, a_{4} \cdot r\right) .
\end{aligned}
$$

The operations of $\vee(\max )$ and $\wedge(\min )$ are defined as follow:

$$
\begin{aligned}
& \tilde{A} \vee \tilde{B} \cong\left(a_{1} \vee b_{1}, a_{2} \vee b_{2}, a_{3} \vee b_{3}, a_{4} \vee b_{4}\right) \\
& \tilde{A} \wedge \tilde{B} \cong\left(a_{1} \wedge b_{1}, a_{2} \wedge b_{2}, a_{3} \wedge b_{3}, a_{4} \wedge b_{4}\right) .
\end{aligned}
$$

- Definition 4. Assumed that a decision group has $K$ decision makers, and the fuzzy rating of each decision maker $D_{k},(k=1,2, \ldots, K)$ can be represented as

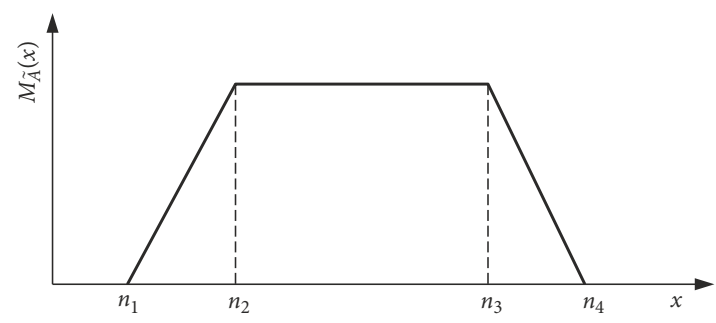

Figure 1. Trapezoidal fuzzy number 
a PTFN $\tilde{R}_{k},(k=1,2, \ldots, K)$ with membership function $M_{\tilde{n}}(x)$. Then the aggregated fuzzy rating can be defined as:

$\tilde{R}=(a, b, c, d), k=1,2, \ldots, K$,

where: $a=\min _{k}\left\{a_{k}\right\}_{k} ; b=\frac{1}{K} ; c=\frac{1}{K}$;

$d=\max _{k}\left\{d_{k}\right\}_{k}$.

$$
k \cdot \sum_{k=1}^{K} b_{k} \quad k \cdot \sum_{k=1}^{K} c_{k}
$$

Let the fuzzy rating and importance weight of the $k$ th decision maker be $\tilde{x}_{i j}^{k}=\left(x_{i j 1}^{k}, x_{i j 2}^{k}, x_{i j 3}^{k}, x_{i j 4}^{k}\right)$ and $\tilde{w}_{i j}^{k}=\left(w_{i j 1}^{k}, w_{i j 2}^{k}, w_{i j 3}^{k}, w_{i j 4}^{k}\right), i=1 \ldots m, j=1 \ldots n$, respectively. Hence, the aggregate fuzzy rating $\tilde{x}_{i j}$ of alternatives with respect to each criterion is calculated as follows:

$$
\begin{aligned}
& \tilde{x}_{i j}=\left(x_{i j 1}, x_{i j 2}, x_{i j 3}, x_{i j 4}\right), \\
& \text { where: } x_{i j 1}=\min \left\{x_{i j k 1}\right\}_{k} ; x_{i j 2}=\frac{1}{k \cdot \sum_{k}^{K} x_{i j k 2}} ; \\
& x_{i j 3}=\frac{1}{k \cdot \sum_{k}^{K} x_{i j k 3}} ; \\
& x_{i j k 4}=\max \left\{x_{i j k 4}\right\}_{k}
\end{aligned}
$$

and the aggregated fuzzy weights $\tilde{w}_{j}$ of each criterion can be calculated as:

$$
\begin{aligned}
& w_{j 1}=\left(w_{j 1}, w_{j 2}, w_{j 3}, w_{j 4}\right), \\
& \text { where: } w_{j 1}=\min \left\{w_{j k 1}\right\}_{k} ; w_{j 2}=\frac{1}{k \cdot \sum_{k}^{K} w_{j k 2}} ; \\
& w_{j 3}=\frac{1}{k \cdot \sum_{k}^{K} w_{j k 3}} ; w_{j 4}=\max \left\{w_{j k 4}\right\}_{k} \cdot
\end{aligned}
$$

\subsection{Additive ratio assessment method}

Zavadskas and Turskis (2010) have developed ARAS method with the basic concept that the events of the complex world could be understood using simple relative comparisons. Based on the method proposed (Tupenaite et al. 2010) a utility function value determining the complex relative efficiency of a feasible alternative is directly proportional to the relative effect of values and weights of the main criteria considered in a project. Due to its easiness it is employed by different researchers to rank the possible alternatives for choosing the best one (Zavadskas, Turskis 2010; Dadelo et al. 2012; Kutut et al. 2013; Zamani et al. 2014). Although the concepts have a profound logic and the computations are straightforward, ARAS does not have the capability to capture the uncertainty and vagueness derived from subjective judgments. Therefore, considering the existing uncertainty is the advantage of using fuzzy logic. First work used this technique in fuzzy environment was developed by Turskis and Zavadskas
(2010) in order to select the logistic centers location to help the stakeholders with the performance evaluation in an uncertain environment. The paper presents a newlydeveloped FARAS method to solve different problems in technology, transport construction, and economics development. Most recently ARAS method has been used solely (Shariati et al. 2014; Stanujkic 2015) or along with other MCDM techniques like; AHP (Turskis et al. 2012; Keršulienė, Turskis 2014; Büyüközkan, Göçer 2018; Ecer 2018); TOPSIS and VIKOR (Baležentis et al. 2012); ANP (Zamani et al. 2014; Ghadikolaei et al. 2014); SWARA (Keršulienė, Turskis 2011; Dahooie et al. 2018), FCOPRAS and FMOORA (Akhavan et al. 2015). It should be maintained that although some studies have developed FARAS method (Turskis, Zavadskas 2010; Akhavan et al. 2015; Stanujkic 2015; Zamani et al. 2014; Rostamzadeh et al. 2017; Turskis et al. 2012), they mostly used triangular fuzzy numbers to capture the uncertainty, which are the special case of trapezoidal fuzzy numbers. Hence, in this research trapezoidal fuzzy numbers were used which can encompass more uncertainty than the triangular fuzzy number.

For this study, ARAS method was developed in fuzzy environments using trapezoidal fuzzy numbers as following steps:

- Step 1. The objectives in the decision-making process must be identified and the scope of the problem must be defined;

- Step 2. The decision-making group must be arranged, and then a finite set of relevant attributes must be defined and described accordingly. The authors have identified seven main criteria and forty three sub-criteria over four different supply chains to be caparisoned. The metrics in the study were selected with a thorough literature review represented in Table 1;

- Step 3. The proper linguistic variables must be identified. In this step for the evaluation of the importance weights of the metrics and rating of the alternatives the linguistic variables are determined. PTFN linguistic variables shown in Table 2 is used to evaluate the importance of the metrics and alternatives with respect to qualitative criteria;

- Step 4. To construct the fuzzy decision matrix, the aggregated fuzzy weights of the metrics and the aggregated fuzzy ranking of the alternatives are derived from decision makers by using Equations (8)-(10).

A decision matrix, $\mathrm{D}$, of $\mathrm{m} \times \mathrm{n}$ dimension is defined as in Equation (11):

$$
D=\left(\begin{array}{ccccc}
\tilde{x}_{01} & \ldots & \tilde{x}_{0 j} & \ldots & \tilde{x}_{0 n} \\
\vdots & \ddots & \vdots & \ddots & \vdots \\
\tilde{x}_{i 1} & \ldots & \tilde{x}_{i j} & \ldots & \tilde{x}_{i n} \\
\vdots & \ddots & \vdots & \ddots & \vdots \\
\tilde{x}_{m 1} & \ldots & \tilde{x}_{m j} & \ldots & \tilde{x}_{m n}
\end{array}\right), i=0 \ldots m, j=1 \ldots n,
$$

where: $m$ is number of alternatives; $n$ is number of criteria describing each alternative; $\tilde{x}_{i j}$ is fuzzy value representing the performance value of the $i$ alternative in terms of the $j$ criterion; $\tilde{x}_{0 j}$ optimal value of $j$ criterion. 
If optimal value of $j$ criterion is unknown, then:

$\tilde{x}_{0 j}=\max \tilde{x}_{i j}$, if $\max \tilde{x}_{i j}$ is preferable;

$\tilde{x}_{0 j}=\min \tilde{x}_{i j}^{*}$, if $\min \tilde{x}_{i j}^{*}$ is preferable;

- Step 5. The fuzzy decision matrix and fuzzy weight of each criterion are defuzzified into crisp values. The crisp value of the fuzzy number $\tilde{A}$ based on COA method can be expressed by following relation:

$\bar{x}_{0}(\tilde{A})=\frac{\int x \cdot \mu_{\tilde{A}}(x) \mathrm{d} x}{\int \mu_{\tilde{A}}(x) \mathrm{d} x}$,

where: $\bar{x}_{0}(\tilde{A})$ is the defuzzified value.

For PTFN, the centroid-based defuzzified value turns out to be (Liu et al. 2012):

$$
\begin{aligned}
& \bar{x}_{0}(\tilde{A})=\frac{1}{3} \cdot\left(a_{1}+a_{2}+a_{3}+a_{4}-\right. \\
& \left.\frac{a_{4} \cdot a_{3}-a_{1} \cdot a_{2}}{\left(a_{4}+a_{3}\right)-\left(a_{1}+a_{2}\right)}\right)
\end{aligned}
$$

- Step 6. The initial values of all the metrics are normalized. The metrics, whose preferable values are maxima, are normalized as follows:

$$
\tilde{\bar{x}}_{i j}=\frac{\tilde{x}_{i j}}{\sum_{i=0}^{m} \tilde{x}_{i j}} \text {. }
$$

The criteria, whose preferable values are minima, are normalized by applying two-stage procedure:

$$
\begin{aligned}
& \tilde{x}_{i j}=\frac{1}{\tilde{x}_{i j}^{*}} ; \\
& \tilde{\bar{x}}_{i j}=\frac{\tilde{x}_{i j}}{\sum_{i=0}^{m} \tilde{x}_{i j}} .
\end{aligned}
$$

When the dimensionless values of the criteria are known, all the criteria, originally having different dimensions, can be compared;

- Step 7. Define normalized-weighted matrix $\tilde{\hat{X}}$. It is possible to evaluate the criteria with weights $0<\tilde{w}_{j}<1$. The sum of weights would be limited as follows:

$$
\sum_{j=1}^{n} \tilde{w}_{j}=1 .
$$

Normalized-weighted values of all the criteria are calculated as follows:

$\tilde{\hat{x}}_{i j}=\tilde{\bar{x}}_{i j} \cdot \tilde{w}_{j}, i=0 \ldots m$,

where: $\tilde{w}_{j}$ is the weight (importance) of the $j$ criterion; $\bar{x}_{i j}$ is the normalized rating of the $j$ criterion;

- Step 8. Determine values of optimality via:

$$
\tilde{S}_{i}=\sum_{j=1}^{n} \tilde{\hat{x}}_{i j}, i=0 \ldots m,
$$

where: $\tilde{S}_{i}$ is the value of optimality function of $i$ th alternative. The biggest value is the best, and the least one is the worst. Therefore, the greater the value of the optimality function $\tilde{S}_{i}$, the more effective the alternative;

- Step 9. Determine the degree of the alternative utility by comparing of the variant, which is analysed, with the most ideal one $S_{0}$. The equation used for the calculation of the utility degree of an alternative $A_{i}$ is given below:

$$
K_{i}=\frac{S_{i}}{S_{0}} \text {, }
$$

where: $S_{i}$ and $S_{0}$ are the optimal criterion values, obtained from Equation (19). It is clear, that the calculated values $K_{i}$ are in the interval $[0 ; 1]$ and can be ordered in an increasing sequence.

The schematic diagram of the proposed model is presented in Figure 2.

Table 2. Linguistic scales for importance and rating (Liu et al. 2012)

\begin{tabular}{|l|c|l|}
\hline $\begin{array}{c}\text { Linguistic scale for } \\
\text { importance }\end{array}$ & $\begin{array}{c}\text { Triangular fuzzy } \\
\text { scale }\end{array}$ & \multicolumn{1}{|c|}{$\begin{array}{c}\text { Linguistic scale } \\
\text { for rating }\end{array}$} \\
\hline Equal & $(1,1,1,1)$ & Equal \\
\hline Very Poor (VP) & $(0,0,0.1,0.2)$ & Very Low (VL) \\
\hline Poor (P) & $(0.1,0.2,0.2,0.3)$ & Low (L) \\
\hline Medium Poor (MP) & $(0.2,0.3,0.4,0.5)$ & Medium Low (ML) \\
\hline Medium (M) & $(0.4,0.5,0.5,0.6)$ & Medium (M) \\
\hline Medium High (MH) & $(0.5,0.6,0.7,0.8)$ & Medium Good (MG) \\
\hline High (H) & $(0.7,0.8,0.8,0.9)$ & Good (G) \\
\hline Very High (VH) & $(0.8,0.9,1,1)$ & Very Good (VG) \\
\hline
\end{tabular}

\section{An application}

The company is required by the ambitious project to enter in a partnership agreement, which lasts for long time, with a 3PL service provider, which would manage all products distribution and the bases of logistics. It was simply inconceivable for the company to invest large amounts of money in infrastructures, equipment and technologies of "state of the art" for restructuring distribution channels of product without jeopardizing its return on assets. It was expected that restructuring program would give important advantages to the company. It was acknowledged that higher levels of customer service could be established only through outsourcing of distribution. It was highly believed that a 3PL partner could handle flows of logistics through the pipeline of distribution more effectively and efficiently, because of existence of high technologies and economies of scale. Figure 3 illustrates the hierarchal structure of the problem. Accordingly, Table 3 shows the importance weight of the criteria assessed by decision makers (linguistic values). In Table 4 ratings of the alternatives with respect to the main criteria assessed by decision makers given. Importance weight of the criteria assessed by decision makers (fuzzy values) presented in Table 5. 


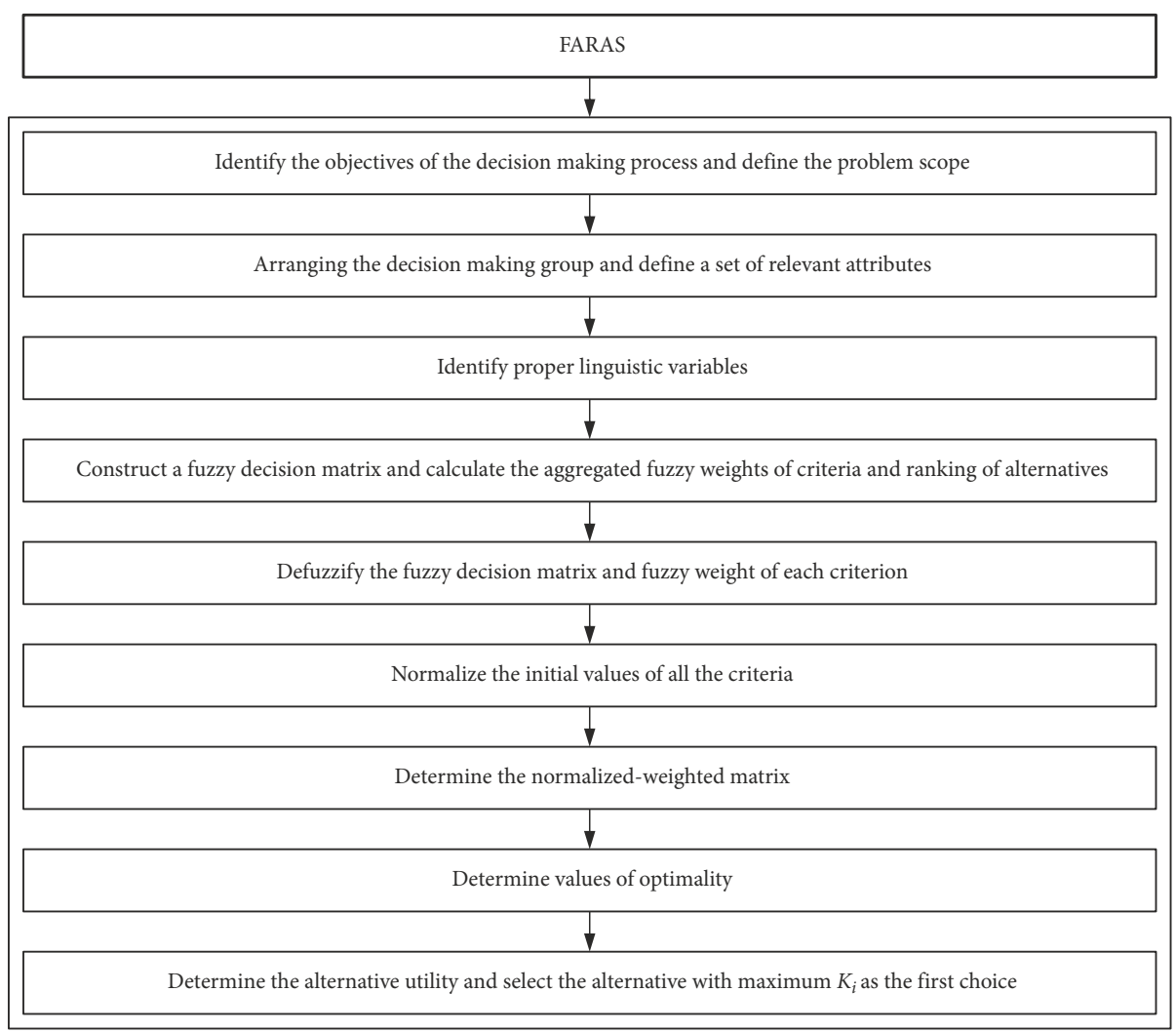

Figure 2. Schematic diagram of the proposed model

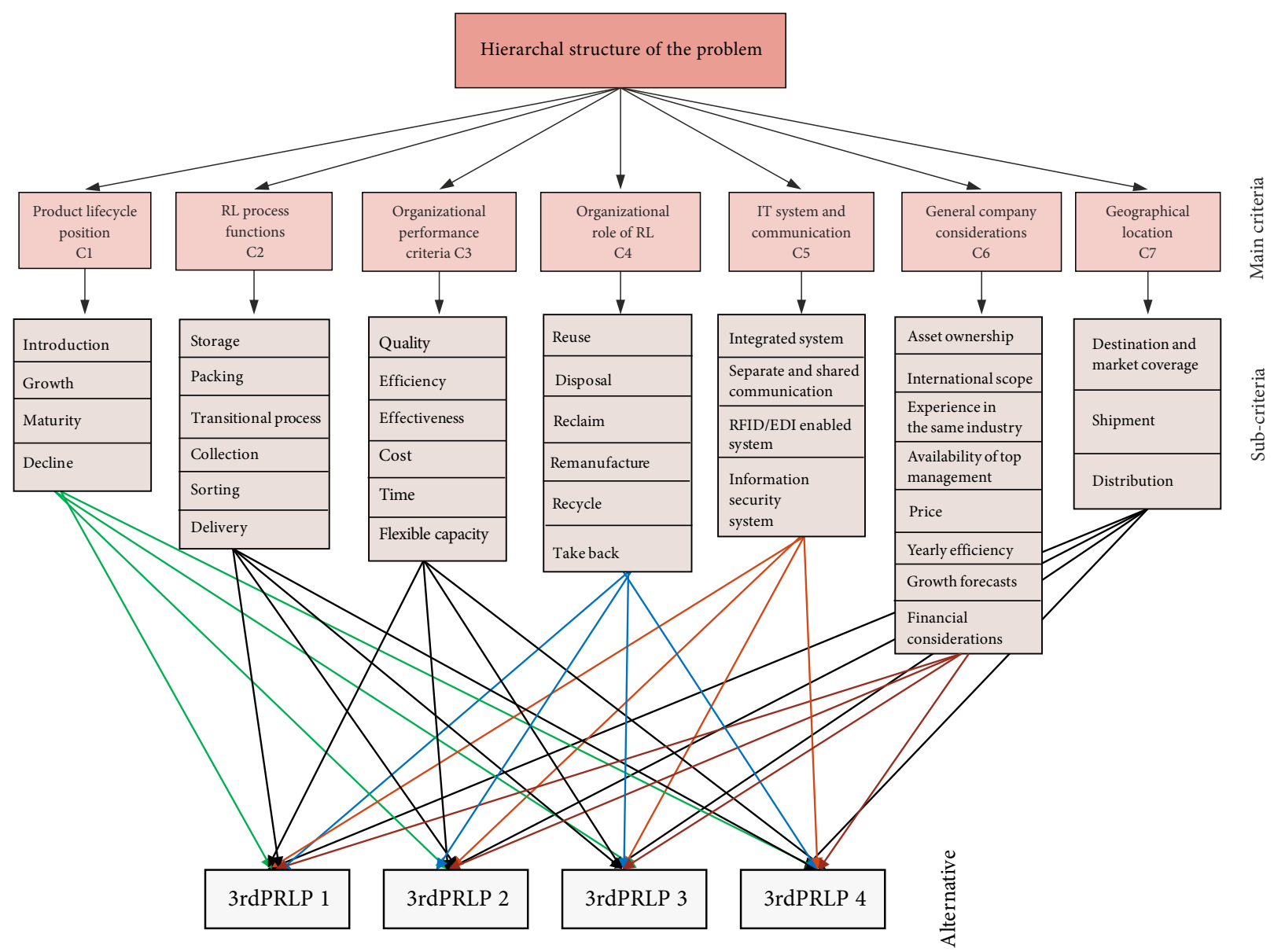

Figure 3. Hierarchy of the problem 
Table 3. Importance weight of the criteria assessed by decision makers (linguistic values)

\begin{tabular}{|c|c|c|c|}
\hline & D1 & D2 & D3 \\
\hline $\mathrm{C} 1$ & $\mathrm{H}$ & $\mathrm{MH}$ & $\mathrm{MH}$ \\
\hline $\mathrm{C} 2$ & $\mathrm{H}$ & $\mathrm{H}$ & $\mathrm{VH}$ \\
\hline $\mathrm{C} 3$ & $\mathrm{VH}$ & $\mathrm{H}$ & $\mathrm{VH}$ \\
\hline $\mathrm{C} 4$ & $\mathrm{H}$ & $\mathrm{MH}$ & $\mathrm{MH}$ \\
\hline $\mathrm{C} 5$ & $\mathrm{MH}$ & $M$ & $\mathrm{M}$ \\
\hline C6 & $\mathrm{M}$ & $\mathrm{MH}$ & $\mathrm{H}$ \\
\hline C7 & $\mathrm{MH}$ & $M$ & $\mathrm{M}$ \\
\hline $\mathrm{C} 11$ & $\mathrm{VH}$ & $\mathrm{H}$ & $\mathrm{H}$ \\
\hline $\mathrm{C} 12$ & $\mathrm{VH}$ & $\mathrm{VH}$ & $\mathrm{H}$ \\
\hline $\mathrm{C} 13$ & $M$ & $\mathrm{ML}$ & $\mathrm{ML}$ \\
\hline C14 & $\mathrm{M}$ & $\mathrm{M}$ & $\mathrm{M}$ \\
\hline C21 & VL & VL & VL \\
\hline C22 & VL & $\mathrm{L}$ & VL \\
\hline C23 & $\mathrm{MH}$ & $\mathrm{H}$ & $\mathrm{H}$ \\
\hline $\mathrm{C} 24$ & $\mathrm{VH}$ & $\mathrm{H}$ & $\mathrm{VH}$ \\
\hline C25 & $\mathrm{MH}$ & $\mathrm{MH}$ & $\mathrm{M}$ \\
\hline C26 & ML & $\mathrm{L}$ & $\mathrm{ML}$ \\
\hline C31 & $\mathrm{ML}$ & $\mathrm{L}$ & $\mathrm{L}$ \\
\hline C32 & $\mathrm{VH}$ & $\mathrm{VH}$ & $\mathrm{VH}$ \\
\hline C33 & $\mathrm{MH}$ & $\mathrm{MH}$ & $\mathrm{H}$ \\
\hline C34 & $\mathrm{H}$ & $\mathrm{H}$ & $\mathrm{MH}$ \\
\hline C35 & $\mathrm{MH}$ & $M$ & $\mathrm{M}$ \\
\hline C36 & $\mathrm{M}$ & $\mathrm{MH}$ & $\mathrm{MH}$ \\
\hline C41 & $\mathrm{L}$ & $\mathrm{L}$ & $\mathrm{L}$ \\
\hline C42 & VL & $\mathrm{L}$ & $\mathrm{L}$ \\
\hline C43 & $\mathrm{VH}$ & $\mathrm{H}$ & $\mathrm{H}$ \\
\hline C44 & $\mathrm{MH}$ & $\mathrm{MH}$ & $\mathrm{H}$ \\
\hline C45 & $\mathrm{H}$ & $\mathrm{MH}$ & $\mathrm{H}$ \\
\hline C46 & $\mathrm{MH}$ & M & $\mathrm{M}$ \\
\hline C51 & $\mathrm{VH}$ & $\mathrm{H}$ & $\mathrm{H}$ \\
\hline C52 & $\mathrm{ML}$ & $\mathrm{L}$ & $\mathrm{L}$ \\
\hline C53 & $\mathrm{MH}$ & $\mathrm{H}$ & $\mathrm{MH}$ \\
\hline C54 & $\mathrm{H}$ & $\mathrm{H}$ & $\mathrm{H}$ \\
\hline C61 & $\mathrm{VL}$ & $\mathrm{L}$ & $\mathrm{L}$ \\
\hline C62 & M & ML & ML \\
\hline C63 & $\mathrm{M}$ & $\mathrm{MH}$ & $\mathrm{M}$ \\
\hline C64 & $\mathrm{VH}$ & $\mathrm{VH}$ & $\mathrm{H}$ \\
\hline C65 & $\mathrm{H}$ & $\mathrm{VH}$ & $\mathrm{H}$ \\
\hline C66 & $\mathrm{MH}$ & $\mathrm{M}$ & $\mathrm{MH}$ \\
\hline C67 & $\mathrm{ML}$ & $\mathrm{L}$ & $\mathrm{L}$ \\
\hline C68 & $\mathrm{VH}$ & $\mathrm{VH}$ & $\mathrm{VH}$ \\
\hline C71 & $\mathrm{H}$ & $\mathrm{VH}$ & $\mathrm{VH}$ \\
\hline $\mathrm{C} 72$ & $M$ & $\mathrm{MH}$ & $\mathrm{M}$ \\
\hline C73 & $\mathrm{H}$ & $\mathrm{VH}$ & $\mathrm{H}$ \\
\hline
\end{tabular}

Note: abbreviations available in Table 2.
Table 4. Ratings of the alternatives with respect to the main criteria assessed by decision makers

\begin{tabular}{|c|c|c|c|c|c|c|c|c|c|c|c|c|}
\hline & \multicolumn{4}{|c|}{ D1 } & \multicolumn{4}{|c|}{ D2 } & \multicolumn{4}{|c|}{ D3 } \\
\hline & $\mathrm{A} 1$ & $\mathrm{~A} 2$ & A3 & $\mathrm{A} 4$ & A1 & $\mathrm{A} 2$ & A3 & $\mathrm{A} 4$ & $\mathrm{~A} 1$ & A2 & A3 & A4 \\
\hline $\mathrm{C} 1$ & $\mathrm{MP}$ & G & IG & $M$ & G & G & G & G & VG & VG & G & $\mathrm{MG}$ \\
\hline $\mathrm{C} 2$ & $\mathrm{MG}$ & G & $\mathrm{M}$ & $\mathrm{MG}$ & G & G & MG & VG & VG & VG & G & $\mathrm{G}$ \\
\hline $\mathrm{C} 3$ & VG & G & VG & G & G & VG & VG & VG & VG & VG & G & VG \\
\hline $\mathrm{C} 4$ & M & $\mathrm{M}$ & M & $\mathrm{M}$ & MG & $\mathrm{M}$ & M & $\mathrm{MG}$ & MG & G & MG & G \\
\hline C5 & $\mathrm{M}$ & MG & $\mathrm{MG}$ & $\mathrm{M}$ & $M$ & $\mathrm{M}$ & $\mathrm{M}$ & $\mathrm{MG}$ & MG & $\mathrm{M}$ & $\mathrm{M}$ & MG \\
\hline C6 & MP & M & M & $\mathrm{MG}$ & MG & MG & $\mathrm{M}$ & $\mathrm{M}$ & $\mathrm{MP}$ & $\mathrm{M}$ & $\mathrm{M}$ & MP \\
\hline C7 & M & MG & MG & G & G & G & MG & MG & MG & VG & G & G \\
\hline C11 & G & VG & G & $\mathrm{MG}$ & G & VG & G & G & $\mathrm{MG}$ & G & G & G \\
\hline $\mathrm{C} 12$ & $\mathrm{VG}$ & $G$ & $G$ & $G$ & $G$ & $G$ & $G$ & $\mathrm{VG}$ & $\mathrm{MG}$ & $G$ & $\mathrm{MG}$ & $G$ \\
\hline C13 & $M$ & MG & $M$ & MP & MP & $M$ & MG & $M$ & $M$ & $M$ & MP & $\mathrm{M}$ \\
\hline C14 & $\mathrm{M}$ & $\mathrm{M}$ & $\mathrm{MG}$ & $\mathrm{MG}$ & $M$ & MG & G & G & $\mathrm{MG}$ & $\mathrm{M}$ & $\mathrm{MP}$ & $\mathrm{M}$ \\
\hline C21 & VP & VP & $\mathrm{P}$ & $\mathrm{P}$ & $\mathrm{MP}$ & $\mathrm{P}$ & $\mathrm{P}$ & $\mathrm{P}$ & VP & $\mathrm{VP}$ & $\mathrm{P}$ & $\mathrm{P}$ \\
\hline C22 & VP & MP & $\mathrm{P}$ & $\mathrm{P}$ & VP & $\mathrm{P}$ & $\mathrm{P}$ & $\mathrm{P}$ & MP & VP & $\mathrm{P}$ & $\mathrm{P}$ \\
\hline $\mathrm{C} 23$ & G & G & G & $G$ & $G$ & $\mathrm{MG}$ & MG & $G$ & $G$ & G & $\mathrm{MG}$ & G \\
\hline C24 & $G$ & VG & $\mathrm{G}$ & VG & $G$ & $G$ & $G$ & VG & $\mathrm{MG}$ & $\mathrm{VG}$ & $G$ & $\mathrm{VG}$ \\
\hline C25 & MG & G & G & G & VG & G & MG & MG & G & G & MG & G \\
\hline C26 & MP & $\mathrm{P}$ & $\mathrm{P}$ & MP & $M$ & $\mathrm{M}$ & $\mathrm{M}$ & $\mathrm{M}$ & $\mathrm{MP}$ & $\mathrm{M}$ & $\mathrm{MP}$ & $\mathrm{M}$ \\
\hline C31 & 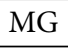 & G & M & Iv & M & $\mathrm{G}$ & $\mathrm{M}$ & $\mathrm{M}$ & $\bar{M}$ & $\mathrm{IP}$ & $\mathrm{M}$ & $\mathrm{M}$ \\
\hline C32 & VG & VG & G & VG & $G$ & VG & G & G & G & VG & G & VG \\
\hline C33 & $\mathrm{MP}$ & $\mathrm{M}$ & $M$ & MP & $\mathrm{P}$ & $\mathrm{M}$ & $\mathrm{MP}$ & $\mathrm{M}$ & $\mathrm{P}$ & $\mathrm{MP}$ & $\mathrm{P}$ & $\mathrm{P}$ \\
\hline C34 & $\mathrm{M}$ & $\mathrm{M}$ & MP & $\mathrm{P}$ & $M$ & $M$ & MP & $\mathrm{IP}$ & $\mathrm{M}$ & $\mathrm{MG}$ & $\mathrm{M}$ & $\mathrm{M}$ \\
\hline C35 & $\mathrm{G}$ & G & G & G & G & $M$ & $\mathrm{~N}$ & $\mathrm{G}$ & G & VG & G & $\mathrm{G}$ \\
\hline C36 & MP & MG & $M$ & $M$ & $\mathrm{MP}$ & $\mathrm{MG}$ & $M$ & $M$ & $\mathrm{MP}$ & $M$ & $\mathrm{P}$ & $\mathrm{P}$ \\
\hline C41 & G & VG & G & G & MG & G & MG & $\mathrm{MG}$ & $\mathrm{MG}$ & $\mathrm{M}$ & $\mathrm{M}$ & $\mathrm{M}$ \\
\hline C42 & $M$ & $M$ & M & G & MG & MG & $\mathrm{M}$ & $M$ & $\mathrm{M}$ & MG & $\mathrm{M}$ & $\mathrm{M}$ \\
\hline C43 & $\mathrm{M}$ & $\mathrm{MP}$ & MP & $\mathrm{P}$ & $M$ & $\mathrm{MP}$ & $\mathrm{M}$ & $\mathrm{M}$ & MP & $\mathrm{MP}$ & $\mathrm{M}$ & $\mathrm{P}$ \\
\hline C44 & $G$ & $G$ & $G$ & $\mathrm{MG}$ & $M$ & $\mathrm{G}$ & $\mathrm{MG}$ & $\mathrm{MG}$ & $G$ & $G$ & $\mathrm{M}$ & $G$ \\
\hline C45 & $\mathrm{MP}$ & $\mathrm{P}$ & $\mathrm{P}$ & $\mathrm{P}$ & $\mathrm{M}$ & $\mathrm{MP}$ & $\mathrm{P}$ & M & $\mathrm{M}$ & $\mathrm{MP}$ & $\mathrm{MP}$ & $\mathrm{P}$ \\
\hline C46 & G & $\mathrm{VC}$ & G & MG & C & MG & MG & G & MG & M & M & $\mathrm{M}$ \\
\hline C51 & VG & G & G & G & MG & MG & G & $\mathrm{M}$ & $\mathrm{MG}$ & G & MG & $\mathrm{M}$ \\
\hline C52 & MP & $M$ & MP & $\mathrm{P}$ & $M$ & $M$ & $M$ & $M$ & MP & MG & $M$ & MP \\
\hline C53 & $\mathrm{P}$ & MP & 10 & $\mathrm{P}$ & $\mathrm{P}$ & $\mathrm{MP}$ & $\mathrm{P}$ & $\mathrm{M}$ & MP & $\mathrm{M}$ & $\mathrm{MP}$ & $\mathrm{P}$ \\
\hline C54 & M & MG & M & M & G & G & MG & MG & M & M & MP & MP \\
\hline C61 & $\mathrm{M}$ & MG & $\mathrm{MG}$ & $\mathrm{MG}$ & $\mathrm{M}$ & $\mathrm{MP}$ & $\mathrm{P}$ & $\mathrm{MP}$ & $\mathrm{M}$ & $\mathrm{MG}$ & $\mathrm{M}$ & $\mathrm{M}$ \\
\hline C62 & $P$ & MP & MP & $\mathrm{D}$ & $\mathrm{M}$ & $\mathrm{M}$ & $\mathrm{M}$ & $\mathrm{M}$ & $\mathrm{MG}$ & MG & $\mathrm{M}$ & $\mathrm{M}$ \\
\hline C63 & MG & G & G & G & IG & MG & MG & $\mathrm{M}$ & $\mathrm{M}$ & $\mathrm{M}$ & $\mathrm{M}$ & MP \\
\hline C64 & G & G & $\mathrm{MG}$ & $\mathrm{MG}$ & VG & VG & MG & G & G & G & $\mathrm{G}$ & VG \\
\hline C65 & $\mathrm{MG}$ & MG & $\mathrm{M}$ & $\mathrm{M}$ & $\mathrm{M}$ & $\mathrm{MP}$ & MG & G & G & G & MG & $\mathrm{M}$ \\
\hline C66 & MP & $\mathrm{P}$ & $\mathrm{M}$ & MP & $\mathrm{M}$ & MG & M & MG & MG & MG & $\mathrm{M}$ & $\mathrm{M}$ \\
\hline C67 & VP & $\mathrm{P}$ & $\mathrm{P}$ & $\mathrm{P}$ & $\mathrm{P}$ & MP & MP & $\mathrm{P}$ & $\mathrm{P}$ & $\mathrm{P}$ & $\mathrm{P}$ & VP \\
\hline C68 & G & G & G & G & VG & VG & G & VG & $\mathrm{G}$ & VG & MG & G \\
\hline C71 & G & VG & G & G & MG & G & G & G & MG & G & G & $\mathrm{M}$ \\
\hline $\mathrm{C} 72$ & IG & G & $G$ & $M$ & MG & $M$ & $\mathrm{MP}$ & $M$ & $M$ & $\mathrm{MG}$ & $M$ & $\mathrm{MP}$ \\
\hline C73 & MG & M & M & $\mathrm{M}$ & $\mathrm{M}$ & MG & G & $\mathrm{MG}$ & G & G & MG & G \\
\hline
\end{tabular}

Note: abbreviations available in Table 2. 
Table 5. Importance weight of the criteria assessed by decision makers (fuzzy values)

\begin{tabular}{|c|c|c|c|}
\hline & D1 & D2 & D3 \\
\hline $\mathrm{C} 1$ & $.7,0.8,0.8,0.9)$ & $.5,0.6,0.7,0.8)$ & $(0.5,0.6,0.7,0.8)$ \\
\hline $\mathrm{C} 2$ & $.7,0.8,0.8,0.9)$ & $0.7,0.8,0.8,0.9)$ & $(0.8,0.9,1.0,1.0)$ \\
\hline $\mathrm{C} 3$ & ) & $(0.7,0$ & $(0.8$ \\
\hline $\mathrm{C} 4$ & 07 & , 0.8) & $0.8)$ \\
\hline $\mathrm{C} 5$ & $(0.5$, & $(0.4$ & $(0.4$ \\
\hline C6 & .6) & $0.8)$ & $(0.7$ \\
\hline $\mathrm{C} 7$ & $(0.5$, & $(0.4$, & $0.6)$ \\
\hline $\mathrm{C} 11$ & $(0.8$ & $3,0.8,0.9)$ & $0.8,0.9)$ \\
\hline $\mathrm{C} 12$ & $(0.8$, & $0)$ & $(0$. \\
\hline $\mathrm{C} 13$ & $(0.4,0$ & $(0.2$ & $(0.2$ \\
\hline $\mathrm{C} 14$ & $0.6)$ & $(0.4$ & $0.6)$ \\
\hline $\mathrm{C} 21$ & $(0.0,0.0,0.1,0.2)$ & $(0.0,0.0,0.1,0.2)$ & $(0.0,0.0,0.1,0.2)$ \\
\hline $\mathrm{C} 22$ & $0.2)$ & $(0.1,0.2$, & $.0,0.1,0.2)$ \\
\hline $\mathrm{C} 23$ & $(0.5,0.6,0.7,0.8)$ & $(0.7,0.8,0.8,0.9)$ & (0.7, \\
\hline $\mathrm{C} 24$ & (0.8, & $(0.7$ & $(0.8$ \\
\hline $\mathrm{C} 25$ & $(0.5,0.6,0.7,0.8)$ & $(0.5,0.6,0.7,0.8)$ & $(0.4,0.5,0.5,0.6)$ \\
\hline $\mathrm{C} 26$ & $(0.2,0$ & $(0.1$, & $(0.2$ \\
\hline $\mathrm{C} 31$ & $0.5)$ & $(0.1,0.2,0$ & $0.3)$ \\
\hline $\mathrm{C} 32$ & $(0.8,0.9,1.0,1.0)$ & $(0.8,0.9,1.0,1.0)$ & $(0.8,0.9,1.0,1.0)$ \\
\hline $\mathrm{C} 33$ & $(0.5,0.6,0.7,0.8)$ & $(0.5,0.6$ & $(0.7$ \\
\hline C34 & $8,0.8,0.9)$ & $(0.7,0.8,0.8$, & $(0.5$ \\
\hline C35 & $6,0.7,0.8)$ & $(0.4,0.5,0.5,0.6)$ & $.5,0.6)$ \\
\hline C36 & $5,0.5,0.6)$ & $0.8)$ & 8) \\
\hline $\mathrm{C} 41$ & (0.1, & $(0.1$, & $(0.1$ \\
\hline $\mathrm{C} 42$ & ) & 3) & 3) \\
\hline $\mathrm{C} 43$ & $0.8,0.9,1.0,1.0)$ & $(0.7,0.8,0.8,0.9)$ & $(0.7,0.8,0.8,0.9)$ \\
\hline $\mathrm{C} 44$ & $(0.5,0.6,0.7,0.8)$ & $(0.5,0.6,0.7,0.8)$ & $(0.7,0.8,0.8,0.9)$ \\
\hline $\mathrm{C} 45$ & $(0.7,0.8,0.8,0.9)$ & $(0.5,0.6,0.7,0.8)$ & $(0.7,0.8,0.8,0.9)$ \\
\hline $\mathrm{C} 46$ & $(0.5,0.6$ & $(0.4,0.5$, & $(0.4,0.5$ \\
\hline C51 & $(0.8,0.9,1.0,1.0)$ & $(0.7,0.8,0.8,0.9)$ & $(0.7,0.8,0.8,0.9)$ \\
\hline C52 & $(0.2,0.3,0.4,0.5)$ & $(0.1,0.2,0.2,0.3)$ & $(0.1,0.2,0.2,0.3)$ \\
\hline C53 & $(0.5,0.6,0.7,0.8)$ & $(0.7,0.8,0.8,0.9)$ & $(0.5,0.6,0.7,0.8)$ \\
\hline 54 & $(0.7,0.8,0.8,0.9)$ & $(0.7,0.8,0.8,0.9)$ & $(0.7,0.8,0.8,0.9)$ \\
\hline C61 & $(0.0,0.0,0.1,0.2)$ & $(0.1,0.2,0.2,0.3)$ & $(0.1,0.2,0.2,0.3)$ \\
\hline 62 & ) & $(0.2$ & $(0.2$ \\
\hline C63 & $(0.4$, & $(0.5,0.6$, & $(0.4,0.5,0.5,0.6)$ \\
\hline C64 & 0.8 & $(0.8$ & $(0$. \\
\hline C65 & $(0.7,0.8,0.8,0.9)$ & $(0.8,0.9,1.0,1.0)$ & $(0.7,0.8,0.8,0.9)$ \\
\hline C66 & $(0.5,0.6$ & $(0.4,0$. & $(0.5,0.6,0.7,0.8)$ \\
\hline C67 & $(0.2,0.3,0.4,0.5)$ & $(0.1,0.2,0.2,0.3)$ & $(0.1,0.2,0.2,0.3)$ \\
\hline C68 & $(0.8,0.9,1.0,1.0)$ & $(0.8,0.9,1.0,1.0)$ & $(0.8,0.9,1.0,1.0)$ \\
\hline C71 & $(0.7,0.8,0.8,0.9)$ & $(0.8,0.9,1.0,1.0)$ & $(0.8,0.9,1.0,1.0)$ \\
\hline $\mathrm{C} 72$ & $(0.4,0$ & $(0.5,0.6,0$. & $(0.4,0.5,0$. \\
\hline $\mathrm{C} 73$ & $(0.7,0.8,0.8,0.9)$ & $(0.8,0.9,1.0,1.0)$ & $(0.7,0.8,0.8,0.9)$ \\
\hline
\end{tabular}

Table 6 provides Ratings of the alternatives with respect to the main criteria assessed by decision makers (fuzzy values). Then aggregated fuzzy values of alternatives rates and subjective importance weights given in Table 7. Table 8 defuzzified aggregated fuzzy values of firms' rates. Finally normalized values and weighted-normalized values and solution results presented in Tables 9 and 10 respectively.

\section{Discussion and managerial implications}

In this paper, seven main criteria and thirty-seven subcriteria were developed to access the 3rdPRLPs among the practitioners. Based on the results obtained from Table 7, the organizational performance $\mathrm{C} 3$ obtained the first rank with (0.1762), RL process function C2 placed in the second order with (0.1721), product lifecycle position $\mathrm{C} 1$ and organizational role of RL C4 obtained the third rank with (0.1417). General company consideration C6 received the fourth rank with (0.1326) and finally, IT system and communication $\mathrm{C} 5$ and geographical location $\mathrm{C} 7$ received the same weight with (0.1176) and placed in the fifth place. Seven most dominant sub-criteria in each group found to be as follows: growth, collection, quality and efficiency, reclaim, integrated system, financial considerations, destination and market coverage. The practitioners were ranked as: A1 known to be the best 3rdPRLP with 0.6707. A2 placed in the second order with 0.6703 , A3 with 0.6447 and A4 with 0.6245 placed in the third and fourth respectively as shown in Table 8. In product lifecycle position C1 group, growth $\mathrm{C} 12$ with $(0.332)$ placed in the first rank and decline C14 with (0.1908) obtained the last rank. In RL process function C2 group, collection C24 with (0.321) placed in the first and storage $\mathrm{C} 21$ with (0.0287) placed in the last.

In organizational performance criteria $\mathrm{C} 3$ group, quality C31 and efficiency C32 with (0.2072) placed in the first and time C35 with (0.1308) received the last priority. In organizational role of RL C4 group, reclaim C43 with (0.2657) obtained the first rank and disposal C42 with $(0.0468)$ received the lowest rank. In IT system and communication C5 group, integrated system C51 with (0.3048) obtained the first rank and separate and shared communication C52 with (0.1571) received the lowest rank. In general, company consideration C6 group, financial considerations C68 with (0.1931) placed in the first and asset ownership C61 with (0.0311) received the last priority. In geographical location $\mathrm{C} 7$ group, destination and market coverage C71 with (0.378) placed in the first rank and shipment C72 with (0.2524) obtained the last rank.

Organizational performance found out to be the most influencer of firm. Quality, efficiency effectiveness, cost, time and flexible capacity are the strong drivers and must be given preference in achieving the desired outcome for the firm's performance. In Yang et al. (2011) point of view, organizational performance had two dimensions: one dimension is the business performance. That is, shareholders' responsibilities with the objective of gaining maximum profit. Other dimension is the environmental performance, that is, the environmental responsibilities of organizations. 


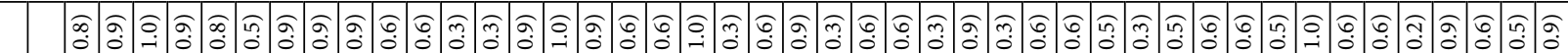

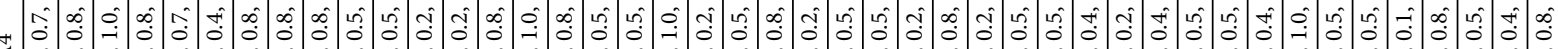

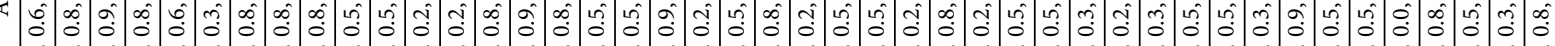

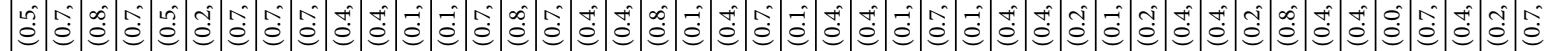

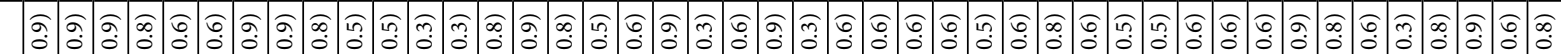

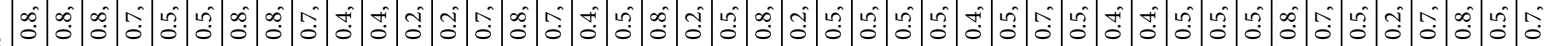

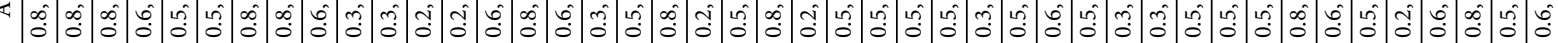

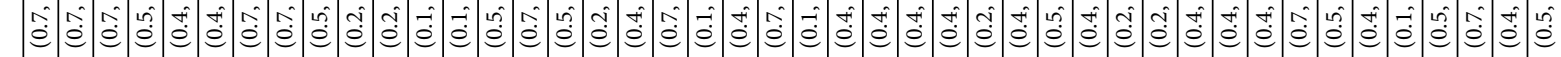
ڤొ

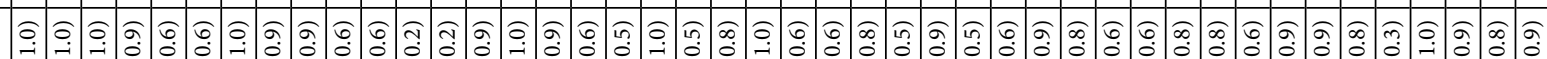

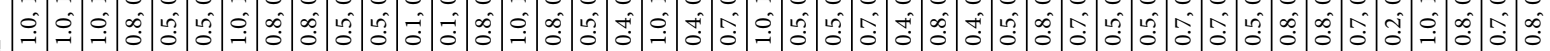

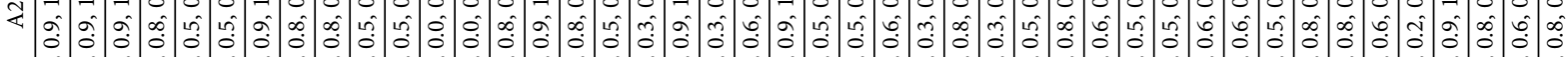

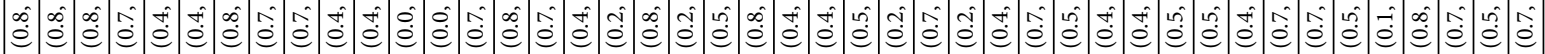

क人

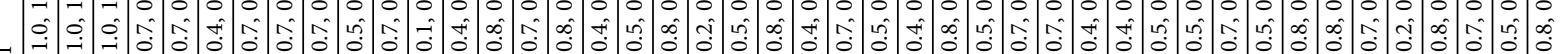

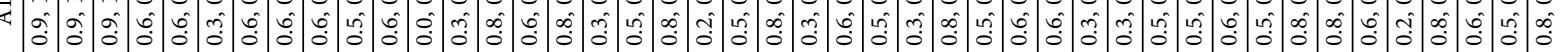

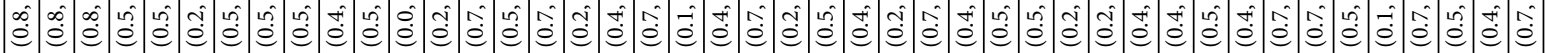

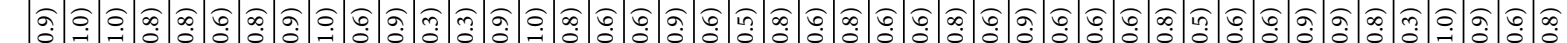

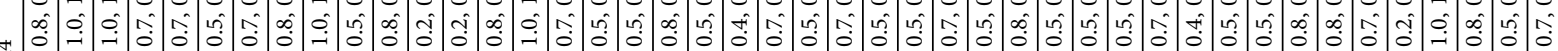

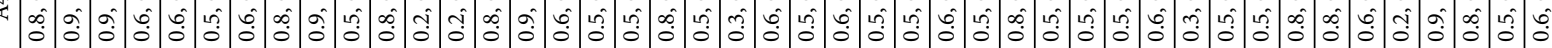

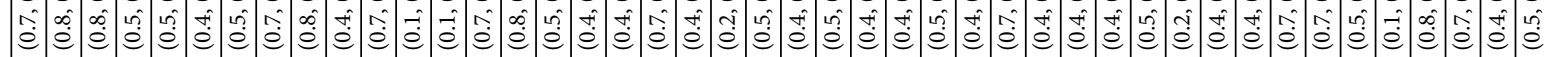

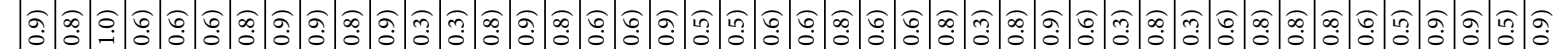

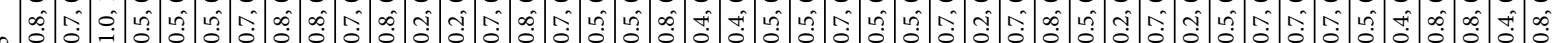

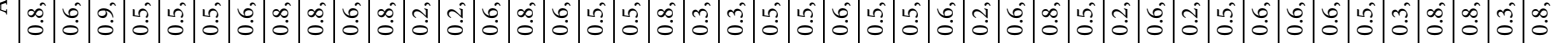

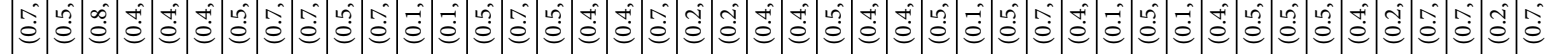
ลี

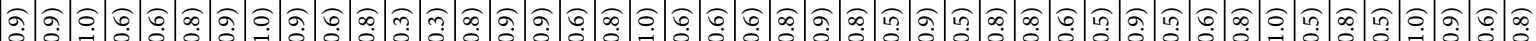

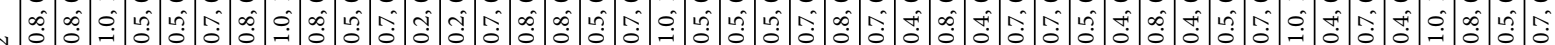

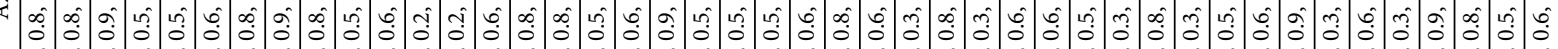

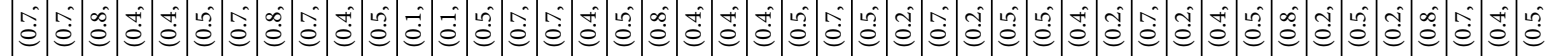

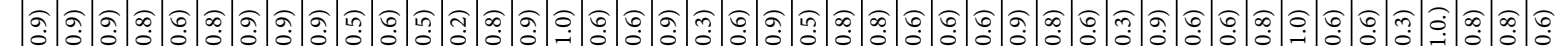

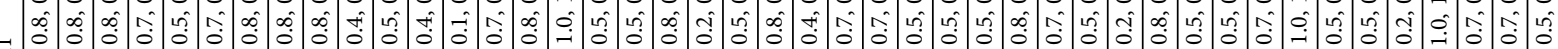

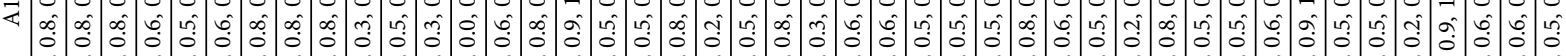

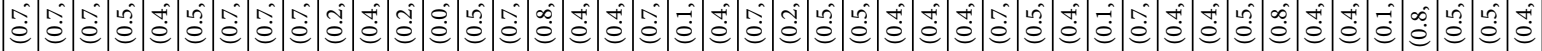

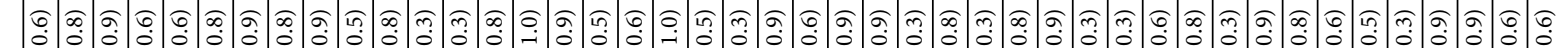

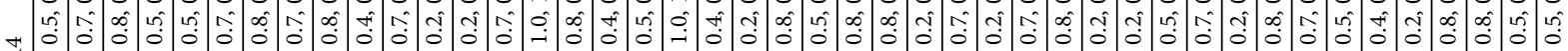

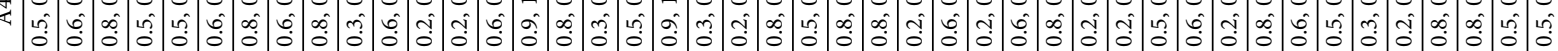

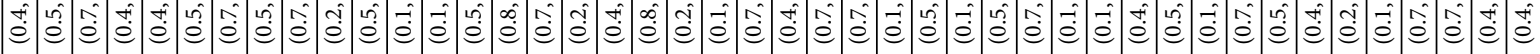

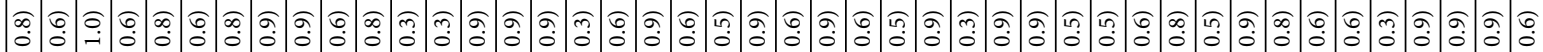

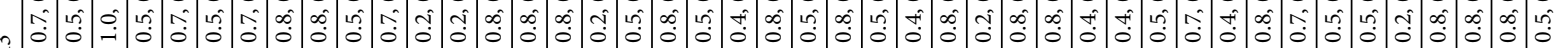

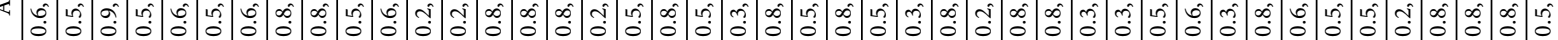

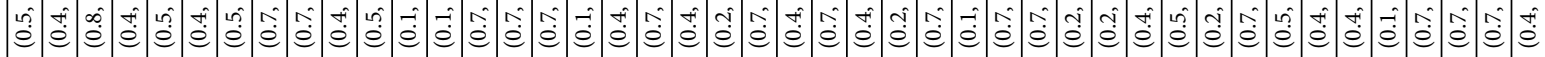
$\overrightarrow{\mathrm{a}}$

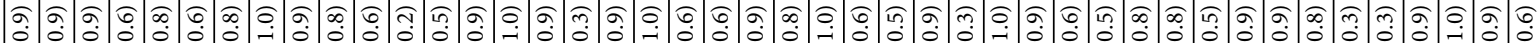

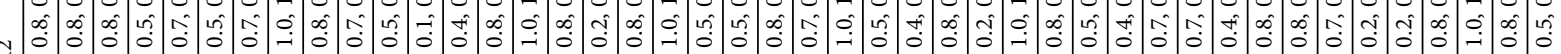

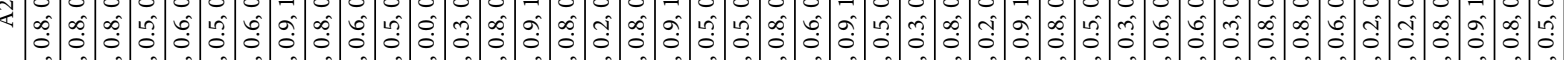

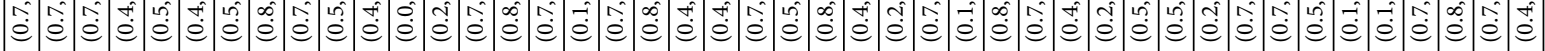

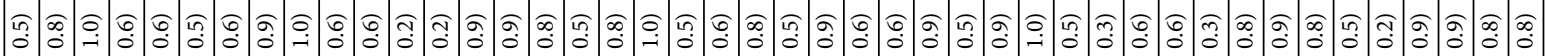

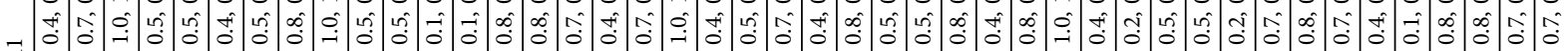

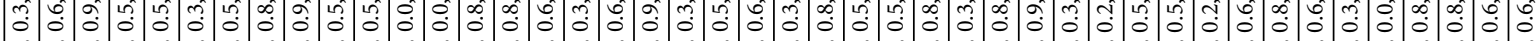

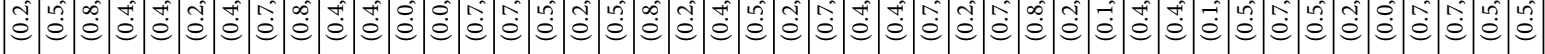
ป 
Table 7. Aggregated fuzzy values of alternatives rates and subjective importance weights

\begin{tabular}{|c|c|c|c|c|c|}
\hline & $W_{j}^{s}$ & A1 & A2 & A3 & A4 \\
\hline $\mathrm{C} 1$ & $(0.50,0.67,0.73,0.90)$ & $(0.20,0.67,0.73,1.00)$ & $(0.70,0.83,0.87,1.00)$ & $(0.50,0.73,0.77,0.09)$ & $(0.40,0.63,0.67,0.90)$ \\
\hline $\mathrm{C} 2$ & $(0.70,0.83,0.87,1.00)$ & $(0.50,0.77,0.83,0.10)$ & $(0.70,0.83,0.87,1.00)$ & $(0.40,0.63,0.67,0.90)$ & $(0.50,0.77,0.83,0.10)$ \\
\hline $\mathrm{C} 3$ & $(0.70,0.87,0.93,1.00)$ & $(0.70,0.87,0.93,1.00)$ & $(0.70,0.87,0.93,1.00)$ & $(0.70,0.87,0.93,1.00)$ & $(0.70,0.87,0.93,1.00)$ \\
\hline $\mathrm{C} 4$ & $(0.50,0.67,0.73,0.90)$ & $(0.40,0.57,0.63,0.80)$ & $(0.40,0.53,0.57,0.80)$ & $(0.40,0.53,0.57,0.80)$ & $(0.40,0.63,0.67,0.90)$ \\
\hline $\mathrm{C} 5$ & $(0.40,0.53,0.57,0.80)$ & $(0.40,0.53,0.57,0.80)$ & $(0.40,0.53,0.57,0.80)$ & $(0.40,0.53,0.57,0.80)$ & $(0.40,0.57,0.63,0.80)$ \\
\hline C6 & $(0.40,0.63,0.67,0.90)$ & $(0.20,0.40,0.50,0.80)$ & $(0.40,0.53,0.57,0.80)$ & $(0.40,0.50,0.50,0.60)$ & $(0.20,0.47,0.53,0.80)$ \\
\hline $\mathrm{C} 7$ & $(0.40,0.53,0.57,0.80)$ & $(0.40,0.63,0.67,0.90)$ & $(0.50,0.77,0.83,0.10)$ & $(0.50,0.67,0.73,0.90)$ & $(0.50,0.73,0.77,0.90)$ \\
\hline $\mathrm{C} 11$ & $(0.70,0.83,0.87,1.00)$ & $(0.50,0.73,0.77,0.90)$ & $(0.70,0.87,0.93,1.00)$ & $(0.70,0.80,0.80,0.90)$ & $(0.50,0.73,0.77,0.90)$ \\
\hline $\mathrm{C} 12$ & $(0.70,0.87,0.93,1.00)$ & $(0.50,0.77,0.83,0.10)$ & $(0.70,0.80,0.80,0.90)$ & $(0.50,0.73,0.77,0.90)$ & $(0.70,0.83,0.87,1.00)$ \\
\hline $\mathrm{C} 13$ & $(0.20,0.37,0.43,0.60)$ & $(0.20,0.43,0.47,0.60)$ & $(0.40,0.53,0.57,0.80)$ & $(0.20,0.47,0.53,0.80)$ & $(0.20,0.43,0.47,0.60)$ \\
\hline $\mathrm{C} 14$ & $(0.40,0.50,0.50,0.60)$ & $(0.40,0.53,0.57,0.80)$ & $(0.40,0.53,0.57,0.80)$ & $(0.20,0.57,0.63,0.90)$ & $(0.40,0.63,0.67,0.90)$ \\
\hline $\mathrm{C} 21$ & $(0.00,0.00,0.10,0.20)$ & $(0.00,0.10,0.20,0.50)$ & $(0.00,0.067,0.13,0.30)$ & $(0.10,0.20,0.20,0.30)$ & $(0.10,0.20,0.20,0.30)$ \\
\hline $\mathrm{C} 22$ & $(0.00,0.07,0.13,0.30)$ & $(0.00,0.10,0.20,0.50)$ & $(0.00,0.17,0.23,0.50)$ & $(0.10,0.20,0.20,0.30)$ & $(0.10,0.02,0.20,0.30)$ \\
\hline $\mathrm{C} 23$ & $(0.50,0.73,0.77,0.90)$ & $(0.50,0.73,0.77,0.90)$ & $(0.50,0.73,0.77,0.90)$ & $(0.50,0.67,0.73,0.90)$ & $(0.05,0.73,0.77,0.90)$ \\
\hline $\mathrm{C} 24$ & $(0.70,0.87,0.93,1.00)$ & $(0.50,0.73,0.77,0.90)$ & $(0.70,0.87,0.93,1.00)$ & $(0.70,0.80,0.80,0.90)$ & $(0.80,0.90,1.00,1.00)$ \\
\hline $\mathrm{C} 25$ & $(0.40,0.57,0.63,0.80)$ & $(0.50,0.77,0.83,0.10)$ & $(0.70,0.80,0.80,0.90)$ & $(0.50,0.67,0.73,0.90)$ & $(0.50,0.73,0.77,0.90)$ \\
\hline $\mathrm{C} 26$ & $(0.10,0.27,0.40,0.50)$ & $(0.20,0.37,0.43,0.60)$ & $(0.10,0.40,0.40,0.60)$ & $(0.01,0.33,0.37,0.60)$ & $(0.20,0.43,0.47,0.60)$ \\
\hline $\mathrm{C} 31$ & $(0.10,0.23,0.27,0.50)$ & $(0.40,0.53,0.57,0.80)$ & $(0.20,0.57,0.63,0.90)$ & $(0.40,0.50,0.50,0.60)$ & $(0.40,0.50,0.50,0.60)$ \\
\hline $\mathrm{C} 32$ & $(0.80,0.90,1.00,1.00)$ & $(0.70,0.83,0.87,1.00)$ & $(0.70,0.87,0.93,1.00)$ & $(0.70,0.80,0.80,0.90)$ & $(0.70,0.87,0.93,1.00)$ \\
\hline $\mathrm{C} 33$ & $(0.50,0.67,0.73,0.90)$ & $(0.10,0.23,0.27,0.50)$ & $(0.20,0.43,0.47,0.60)$ & $(0.10,0.33,0.37,0.60)$ & $(0.10,0.33,0.37,0.60)$ \\
\hline $\mathrm{C} 34$ & $(0.50,0.73,0.77,0.90)$ & $(0.40,0.50,0.50,0.60)$ & $(0.40,0.53,0.57,0.80)$ & $(0.20,0.37,0.43,0.60)$ & $(0.10,0.33,0.37,0.60)$ \\
\hline $\mathrm{C} 35$ & $(0.40,0.53,0.57,0.80)$ & $(0.50,0.73,0.77,0.90)$ & $(0.40,0.73,0.77,1.00)$ & $(0.50,0.73,0.77,0.90)$ & $(0.50,0.73,0.77,0.90)$ \\
\hline $\mathrm{C} 36$ & $(0.40,0.57,0.63,0.80)$ & $(0.20,0.30,0.40,0.50)$ & $(0.40,0.57,0.63,0.80)$ & $(0.10,0.40,0.40,0.60)$ & $(0.10,0.400,0.4,0.60)$ \\
\hline $\mathrm{C} 41$ & $(0.10,0.20,0.20,0.30)$ & $(0.50$ & $(0.40,0.73,0.77,1.00)$ & $(0.4$ & $(0.40,0.63,0.67,0.90)$ \\
\hline $\mathrm{C} 42$ & $(0.00,0.13,0.17,0.30)$ & $(0.40,0.53,0.57,0.80)$ & $(0.40,0.57,0.63,0.80)$ & $(0.40,0.50,0.50,0.60)$ & $(0.40,0.60,0.60,0.90)$ \\
\hline $\mathrm{C} 43$ & $(0.70,0.83,0.87,1.00)$ & $(0.20,0.43,0.47,0.60)$ & $(0.20,0.30,0.40,0.50)$ & $(0.20,0.43,0.47,0.60)$ & $(0.10,0.30,0.30,0.60)$ \\
\hline C44 & $(0.50,0.67,0.73,0.90)$ & $(0.40,0.70,0.07,0.90)$ & $(0.70,0.80,0.80,0.90)$ & $(0.40,0.63,0.67,0.90)$ & $(0.50,0.67,0.73,0.90)$ \\
\hline $\mathrm{C} 45$ & $(0.50,0.73,0.77,0.90)$ & $(0.20,0.43,0.47,0.60)$ & $(0.10,0.27,0.33,0.50)$ & $(0.10,0.23,0.27,0.50)$ & $(0.10,0.30,0.30,0.60)$ \\
\hline $\mathrm{C} 46$ & $(0.40,0.53,0.57,0.80)$ & $(0.50,0.73,0.77,0.90)$ & $(0.40,0.67,0.73,1.00)$ & $(0.40,0.63,0.67,0.90)$ & $(0.40,0.63,0.67,0.90)$ \\
\hline C51 & $(0.70,0.83,0.87,1.00)$ & $(0.50,0.70,0.80,0.10)$ & $(0.50,0.73,0.77,0.90)$ & $(0.50,0.73,0.77,0.90)$ & $(0.40,0.60,0.60,0.90)$ \\
\hline C52 & $(0.10,0.23,0.27,0.50)$ & $(0.20,0.37,0.43,0.60)$ & $(0.40,0.53,0.57,0.80)$ & $(0.20,0.43,0.47,0.60)$ & $(0.10,0.33,0.37,0.60)$ \\
\hline C53 & $(0.50,0.67,0.73,0.90)$ & $(0.10$, & $(0.20$ & $(0.10$ & $(0.10,0.2$ \\
\hline C54 & $(0.70,0.80,0.80,0.90)$ & $(0.40,0.60,0.60,0.90)$ & $(0.40,0.63,0.67,0.90)$ & $(0.20,0.47,0.53,0.80)$ & $(0.20,0.47,0.53,0.80)$ \\
\hline C61 & $(0.00,0.13,0.17,0.30)$ & $(0.40,0.50,0.50,0.60)$ & $(0.20,0.50,0.60,0.80)$ & $(0.10,0.43,0.47,0.80)$ & $(0.20,0.47,0.53,0.80)$ \\
\hline C62 & $(0.20,0.37,0.43,0.60)$ & $(0.10,0.43,0.47,0.80)$ & $(0.20,0.47,0.53,0.80)$ & $(0.20,0.43,0.47,0.60)$ & $(0.10,0.40,0.40,0.80)$ \\
\hline C63 & $(0.40,0.53,0.57,0.80)$ & $(0.40,0.57,0.63,0.80)$ & $(0.40,0.63,0.67,0.90)$ & $(0.40,0.63,0.67,0.90)$ & $(0.20,0.53,0.57,0.90)$ \\
\hline $\mathrm{C} 64$ & $(0.70,0.87,0.93,1.00)$ & $(0.70,0.83,0.87,1.00)$ & $(0.70,0.83,0.87,1.00)$ & $(0.50,0.67,0.73,0.90)$ & $(0.50,0.77,0.83,0.10)$ \\
\hline $\mathrm{C} 65$ & $(0.70,0.83,0.87,1.00)$ & $(0.40,0.63,0.67,0.90)$ & $(0.20,0.53,0.63,0.90)$ & $(0.40,0.57,0.63,0.80)$ & $(0.40,0.57,0.63,0.80)$ \\
\hline C66 & $(0.40,0.57,0.63,0.80)$ & $(0.20,0.47,0.53,0.80)$ & $(0.10,0.47,0.53,0.80)$ & $(0.40,0.50,0.50,0.60)$ & $(0.20,0.47,0.53,0.80)$ \\
\hline C67 & $(0.10,0.23,0.27,0.50)$ & $(0.00,0.13,0.17,0.30)$ & $(0.10,0.23,0.27,0.50)$ & $(0.10,0.23,0.27,0.50)$ & $(0.00,0.13,0.17,0.30)$ \\
\hline C68 & $(0.80,0.90,1.00,1.00)$ & $(0.7,0.83,0.87,1.00)$ & $(0.70,0.87,0.93,1.00)$ & $(0.50,0.73,0.77,0.90)$ & $(0.70,0.83,0.87,0.90)$ \\
\hline C71 & $(0.70,0.87,0.93,1.00)$ & $(0.50,0.67,0.73,0.09)$ & $(0.70,0.83,0.87,1.00)$ & $(0.70,0.80,0.80,0.90)$ & $(0.40,0.70,0.70,0.90)$ \\
\hline $\mathrm{C} 72$ & $(0.40,0.53,0.57,0.80)$ & $(0.40,0.57,0.63,0.08)$ & $(0.40,0.63,0.67,0.90)$ & $(0.20,0.53,0.57,0.90)$ & $(0.20,0.43,0.47,0.60)$ \\
\hline $\mathrm{C} 73$ & $(0.70,0.83,0.87,1.00)$ & $(0.40,0.63,0.67,0.90)$ & $(0.40,0.63,0.67,0.90)$ & $(0.40,0.63,0.67,0.90)$ & $(0.40,0.63,0.67,0.90)$ \\
\hline
\end{tabular}


Table 8. Defuzzified aggregated fuzzy values of firms' rates

\begin{tabular}{|c|c|c|c|c|c|c|}
\hline & $W_{j}^{s}$ & A0 & A1 & A2 & A3 & A4 \\
\hline $\mathrm{C} 1$ & $(0.700)$ & $(0.920)$ & $(0.635)$ & $(0.850)$ & $(0.718)$ & $(0.655)$ \\
\hline $\mathrm{C} 2$ & $(0.850)$ & $(0.920)$ & $(0.768)$ & $(0.850)$ & $(0.655)$ & $(0.768)$ \\
\hline $\mathrm{C} 3$ & $(0.870)$ & $(0.920)$ & $(0.870)$ & $(0.870)$ & $(0.870)$ & $(0.870)$ \\
\hline $\mathrm{C} 4$ & $(0.700)$ & $(0.920)$ & $(0.600)$ & $(0.581)$ & $(0.581)$ & $(0.655)$ \\
\hline $\mathrm{C} 5$ & $(0.581)$ & $(0.920)$ & $(0.581)$ & $(0.581)$ & $(0.581)$ & $(0.600)$ \\
\hline C6 & $(0.655)$ & $(0.920)$ & $(0.533)$ & $(0.581)$ & $(0.500)$ & $(0.500)$ \\
\hline $\mathrm{C} 7$ & $(0.581)$ & $(0.920)$ & $(0.655)$ & $(0.768)$ & $(0.700)$ & $(0.718)$ \\
\hline $\mathrm{C} 11$ & $(0.850)$ & $(0.920)$ & $(0.718)$ & $(0.870)$ & $(0.800)$ & $(0.718)$ \\
\hline $\mathrm{C} 12$ & $(0.870)$ & $(0.920)$ & $(0.768)$ & $(0.800)$ & $(0.718)$ & $(0.850)$ \\
\hline $\mathrm{C} 13$ & $(0.400)$ & $(0.920)$ & $(0.418)$ & $(0.581)$ & $(0.500)$ & $(0.418)$ \\
\hline $\mathrm{C} 14$ & $(0.500)$ & $(0.920)$ & $(0.581)$ & $(0.581)$ & $(0.567)$ & $(0.655)$ \\
\hline $\mathrm{C} 21$ & $(0.078)$ & $(0.920)$ & $(0.210)$ & $(0.129)$ & $(0.200)$ & $(0.200)$ \\
\hline $\mathrm{C} 22$ & $(0.130)$ & $(0.920)$ & $(0.210)$ & $(0.231)$ & $(0.200)$ & $(0.200)$ \\
\hline $\mathrm{C} 23$ & $(0.718)$ & $(0.920)$ & $(0.718)$ & $(0.718)$ & $(0.700)$ & $(0.718)$ \\
\hline $\mathrm{C} 24$ & $(0.870)$ & $(0.920)$ & $(0.718)$ & $(0.870)$ & $(0.800)$ & $(0.92)$ \\
\hline $\mathrm{C} 25$ & $(0.600)$ & $(0.920)$ & $(0.768)$ & $(0.800)$ & $(0.700)$ & $(0.718)$ \\
\hline $\mathrm{C} 26$ & $(0.314)$ & $(0.920)$ & $(0.400)$ & $(0.367)$ & $(0.350)$ & $(0.418)$ \\
\hline C31 & $(0.920)$ & $(0.920)$ & $(0.581)$ & $(0.567)$ & $(0.500)$ & $(0.500)$ \\
\hline C32 & $(0.920)$ & $(0.920)$ & $(0.850)$ & $(0.870)$ & $(0.800)$ & $(0.870)$ \\
\hline C33 & $(0.700)$ & $(0.920)$ & $(0.438)$ & $(0.418)$ & $(0.400)$ & $(0.350)$ \\
\hline C34 & $(0.718)$ & $(0.350)$ & $(0.500)$ & $(0.581)$ & $(0.400)$ & $(0.350)$ \\
\hline C35 & $(0.581)$ & $(0.717)$ & $(0.718)$ & $(0.717)$ & $(0.718)$ & $(0.718)$ \\
\hline C36 & $(0.600)$ & $(0.920)$ & $(0.350)$ & $(0.600)$ & $(0.367)$ & $(0.367)$ \\
\hline $\mathrm{C} 41$ & $(0.200)$ & $(0.920)$ & $(0.700)$ & $(0.717)$ & $(0.655)$ & $(0.655)$ \\
\hline $\mathrm{C} 42$ & $(0.150)$ & $(0.920)$ & $(0.581)$ & $(0.600)$ & $(0.500)$ & $(0.633)$ \\
\hline $\mathrm{C} 43$ & $(0.850)$ & $(0.920)$ & $(0.418)$ & $(0.350)$ & $(0.418)$ & $(0.330)$ \\
\hline $\mathrm{C} 44$ & $(0.700)$ & $(0.920)$ & $(0.670)$ & $(0.800)$ & $(0.655)$ & $(0.70)$ \\
\hline C45 & $(0.718)$ & $(0.920)$ & $(0.418)$ & $(0.300)$ & $(0.438)$ & $(0.330)$ \\
\hline $\mathrm{C} 46$ & $(0.581)$ & $(0.920)$ & $(0.718)$ & $(0.700)$ & $(0.655)$ & $(0.655)$ \\
\hline C51 & $(0.850)$ & $(0.920)$ & $(0.750)$ & $(0.718)$ & $(0.718)$ & $(0.633)$ \\
\hline C52 & $(0.438)$ & $(0.920)$ & $(0.400)$ & $(0.581)$ & $(0.418)$ & $(0.350)$ \\
\hline C53 & $(0.700)$ & $(0.920)$ & $(0.438)$ & $(0.400)$ & $(0.300)$ & $(0.200)$ \\
\hline C54 & $(0.800)$ & $(0.920)$ & $(0.633)$ & $(0.655)$ & $(0.500)$ & $(0.500)$ \\
\hline C61 & $(0.150)$ & $(0.920)$ & $(0.500)$ & $(0.519)$ & $(0.450)$ & $(0.500)$ \\
\hline C62 & $(0.400)$ & $(0.920)$ & $(0.450)$ & $(0.500)$ & $(0.418)$ & $(0.433)$ \\
\hline C63 & $(0.581)$ & $(0.920)$ & $(0.600)$ & $(0.655)$ & $(0.655)$ & $(0.550)$ \\
\hline C64 & $(0.870)$ & $(0.920)$ & $(0.850)$ & $(0.850)$ & $(0.700)$ & $(0.768)$ \\
\hline C65 & $(0.850)$ & $(0.567)$ & $(0.655)$ & $(0.567)$ & $(0.600)$ & $(0.600)$ \\
\hline C66 & $(0.600)$ & $(0.920)$ & $(0.500)$ & $(0.467)$ & $(0.500)$ & $(0.500)$ \\
\hline C67 & $(0.438)$ & $(0.920)$ & $(0.150)$ & $(0.438)$ & $(0.438)$ & $(0.150)$ \\
\hline C68 & $(0.920)$ & $(0.920)$ & $(0.850)$ & $(0.870)$ & $(0.718)$ & $(0.850)$ \\
\hline C71 & $(0.870)$ & $(0.920)$ & $(0.700)$ & $(0.850)$ & $(0.800)$ & $(0.670)$ \\
\hline $\mathrm{C} 72$ & $(0.581)$ & $(0.920)$ & $(0.600)$ & $(0.655)$ & $(0.550)$ & $(0.418)$ \\
\hline $\mathrm{C} 73$ & $(0.850)$ & $(0.920)$ & $(0.655)$ & $(0.655)$ & $(0.655)$ & $(0.655)$ \\
\hline
\end{tabular}


Table 9. Normalized values of defuzzified values from Table 8

\begin{tabular}{|c|c|c|c|c|c|c|c|}
\hline & $\begin{array}{l}\text { Normal- } \\
\text { ized } W_{j}^{s}\end{array}$ & Rank & A0 & A1 & A2 & A3 & A4 \\
\hline $\mathrm{C} 1$ & $(0.1417)$ & 3 & $(0.243)$ & $(0.168)$ & $(0.224)$ & $(0.19)$ & $(0.173)$ \\
\hline $\mathrm{C} 2$ & $(0.1721)$ & 2 & $(0.232)$ & (0.193) & $(0.214)$ & $(0.165)$ & $(0.193)$ \\
\hline $\mathrm{C} 3$ & $(0.1762)$ & 1 & $(0.209)$ & $(0.197)$ & $(0.197)$ & $(0.197)$ & $(0.197)$ \\
\hline $\mathrm{C} 4$ & $(0.1417)$ & 3 & $(0.275)$ & (0.179) & (0.174) & $(0.174)$ & $(0.196)$ \\
\hline $\mathrm{C} 5$ & $(0.1176)$ & 5 & $(0.281)$ & (0.178) & $(0.178)$ & $(0.178)$ & $(0.183)$ \\
\hline C6 & $(0.1326)$ & 4 & $(0.303)$ & (0.175) & (0.191) & $(0.164)$ & $(0.164)$ \\
\hline $\mathrm{C} 7$ & $(0.1176)$ & 5 & $(0.244)$ & $(0.174)$ & $(0.204)$ & $(0.186)$ & $(0.190)$ \\
\hline $\mathrm{C} 11$ & $(0.3244)$ & 2 & $(0.228)$ & $(0.178)$ & $(0.216)$ & $(0.198)$ & $(0.178)$ \\
\hline $\mathrm{C} 12$ & $(0.3320)$ & 1 & $(0.226)$ & $(0.189)$ & (0.197) & $(0.177)$ & $(0.209)$ \\
\hline C13 & $(0.1526)$ & 4 & $(0.324)$ & $(0.147)$ & $(0.204)$ & $(0.176)$ & $(0.147)$ \\
\hline $\mathrm{C} 14$ & $(0.1908)$ & 3 & $(0.278)$ & (0.175) & (0.175) & $(0.171)$ & $(0.198)$ \\
\hline C21 & $(0.0287)$ & 6 & $(0.554)$ & $(0.126)$ & $(0.077)$ & $(0.120)$ & $(0.120)$ \\
\hline C22 & $(0.0479)$ & 5 & $(0.522)$ & (0.119) & (0.131) & $(0.113)$ & $(0.113)$ \\
\hline C23 & $(0.2649)$ & 2 & $(0.243)$ & $(0.190)$ & $(0.190)$ & $(0.185)$ & $(0.190)$ \\
\hline C24 & $(0.3210)$ & 1 & $(0.217)$ & (0.169) & $(0.205)$ & $(0.189)$ & $(0.217)$ \\
\hline C25 & $(0.2214)$ & 3 & $(0.235)$ & (0.196) & (0.204) & $(0.179)$ & $(0.183)$ \\
\hline C26 & $(0.1158)$ & 4 & $(0.374)$ & $(0.162)$ & $(0.149)$ & $(0.142)$ & $(0.170)$ \\
\hline C31 & $(0.2072)$ & 1 & $(0.299)$ & $(0.189)$ & $(0.184)$ & $(0.162)$ & $(0.162)$ \\
\hline C32 & $(0.2072)$ & 1 & $(0.213)$ & $(0.197)$ & $(0.201)$ & $(0.185)$ & $(0.201)$ \\
\hline C33 & $(0.1576)$ & 3 & $(0.364)$ & (0.173) & (0.165) & $(0.158)$ & $(0.138)$ \\
\hline C34 & $(0.1617)$ & 2 & $(0.160)$ & $(0.229)$ & $(0.266)$ & $(0.183)$ & $(0.160)$ \\
\hline C35 & $(0.1308)$ & 5 & $(0.199)$ & $(0.200)$ & $(0.199)$ & $(0.200)$ & $(0.200)$ \\
\hline C36 & $(0.1351)$ & 4 & (0.353) & (0.134) & $(0.23)$ & $(0.140)$ & $(0.140)$ \\
\hline C41 & $(0.0625)$ & 5 & $(0.252)$ & $(0.191)$ & $(0.196)$ & $(0.179)$ & $(0.179)$ \\
\hline $\mathrm{C} 42$ & $(0.0468)$ & 6 & $(0.284)$ & (0.179) & $(0.185)$ & $(0.154)$ & $(0.195)$ \\
\hline C43 & $(0.2657)$ & 1 & $(0.377)$ & $(0.171)$ & $(0.143)$ & $(0.171)$ & $(0.135)$ \\
\hline C44 & $(0.2188)$ & 3 & $(0.245)$ & (0.178) & $(0.213)$ & $(0.174)$ & $(0.186)$ \\
\hline C45 & $(0.2244)$ & 2 & $(0.382)$ & $(0.173)$ & $(0.124)$ & $(0.182)$ & $(0.137)$ \\
\hline C46 & $(0.1816)$ & 4 & $(0.252)$ & $(0.196)$ & $(0.191)$ & \begin{tabular}{|l|}
$(0.179)$ \\
\end{tabular} & $(0.179)$ \\
\hline C51 & $(0.3048)$ & 1 & $(0.246)$ & $(0.200)$ & $(0.192)$ & $(0.192)$ & $(0.169)$ \\
\hline C52 & $(0.1571)$ & 4 & $(0.344)$ & $(0.149)$ & $(0.217)$ & $(0.156)$ & $(0.131)$ \\
\hline C53 & $(0.2510)$ & 3 & $(0.407)$ & $(0.193)$ & $(0.177)$ & $(0.132)$ & $(0.088)$ \\
\hline C54 & $(0.2869)$ & 2 & $(0.286)$ & $(0.197)$ & $(0.204)$ & $(0.155)$ & $(0.155)$ \\
\hline C61 & $(0.0311)$ & 8 & $(0.318)$ & (0.173) & (0.179) & $(0.155)$ & $(0.173)$ \\
\hline C62 & $(0.0831)$ & 7 & $(0.338)$ & $(0.165)$ & $(0.183)$ & $(0.153)$ & $(0.159)$ \\
\hline C63 & $(0.1208)$ & 5 & $(0.272)$ & $(0.177)$ & $(0.193)$ & $(0.193)$ & $(0.162)$ \\
\hline C64 & $(0.1809)$ & 2 & $(0.225)$ & $(0.207)$ & $(0.207)$ & $(0.171)$ & $(0.187)$ \\
\hline C65 & $(0.1767)$ & 3 & $(0.189)$ & $(0.219)$ & $(0.189)$ & $(0.200)$ & $(0.200)$ \\
\hline C66 & $(0.1247)$ & 4 & $(0.318)$ & $(0.173)$ & $(0.161)$ & $(0.173)$ & $(0.173)$ \\
\hline C67 & $(0.0910)$ & 6 & $(0.438)$ & $(0.071)$ & $(0.208)$ & $(0.208)$ & $(0.071)$ \\
\hline C68 & $(0.1931)$ & 1 & $(0.218)$ & $(0.201)$ & $(0.206)$ & $(0.170)$ & $(0.201)$ \\
\hline C71 & $(0.3780)$ & 1 & $(0.233)$ & (0.177) & $(0.215)$ & $(0.203)$ & $(0.170)$ \\
\hline C72 & $(0.2524)$ & 3 & $(0.292)$ & $(0.190)$ & $(0.208)$ & $(0.174)$ & $(0.132)$ \\
\hline C73 & $(0.3640)$ & 2 & $(0.259)$ & $(0.185)$ & $(0.185)$ & $(0.185)$ & $(0.185)$ \\
\hline
\end{tabular}

Table 10. Weighted-normalized values and solution results

\begin{tabular}{|c|c|c|c|c|c|}
\hline & A0 & A1 & A2 & A3 & A4 \\
\hline $\mathrm{C} 1$ & $(0.0344)$ & $(0.0238)$ & $(0.0317)$ & $(0.0269)$ & $(0.0245)$ \\
\hline $\mathrm{C} 2$ & $(0.0399)$ & $(0.0332)$ & $(0.0368)$ & $(0.0283)$ & $(0.0332)$ \\
\hline $\mathrm{C} 3$ & $(0.0368)$ & $(0.0347)$ & $(0.0347)$ & $(0.0347)$ & $(0.0347)$ \\
\hline $\mathrm{C} 4$ & $(0.0389)$ & $(0.0253)$ & $(0.0246)$ & $(0.0246)$ & $(0.0277)$ \\
\hline $\mathrm{C} 5$ & $(0.0330)$ & $(0.0209)$ & $(0.0209)$ & $(0.0209)$ & $(0.0215)$ \\
\hline C6 & $(0.0401)$ & $(0.0232)$ & $(0.0253)$ & $(0.0217)$ & $(0.0217)$ \\
\hline $\mathrm{C} 7$ & $(0.0286)$ & $(0.0204)$ & $(0.0239)$ & $(0.0218)$ & $(0.0223)$ \\
\hline $\mathrm{C} 11$ & $(0.0739)$ & $(0.0700)$ & $(0.0042)$ & $(0.0642)$ & $(0.0577)$ \\
\hline $\mathrm{C} 12$ & $(0.0727)$ & $(0.0627)$ & $(0.0654)$ & $(0.0587)$ & $(0.0693)$ \\
\hline $\mathrm{C} 13$ & $(0.0494)$ & $(0.0224)$ & $(0.0311)$ & $(0.0268)$ & $(0.0224)$ \\
\hline $\mathrm{C} 14$ & $(0.0530)$ & $(0.0333)$ & $(0.0333)$ & $(0.0326)$ & $(0.0377)$ \\
\hline $\mathrm{C} 21$ & $(0.0156)$ & $(0.0036)$ & $(0.0022)$ & $(0.0033)$ & $(0.0034)$ \\
\hline $\mathrm{C} 22$ & $(0.0250)$ & $(0.0057)$ & $(0.0062)$ & $(0.0054)$ & $(0.0054$ \\
\hline $\mathrm{C} 23$ & $(0.0643)$ & $(0.0503)$ & $(0.0503)$ & $(0.0490)$ & $(0.0503)$ \\
\hline $\mathrm{C} 24$ & $(0.0696)$ & $(0.0542)$ & $(0.0658)$ & $(0.0606)$ & $(0.0696)$ \\
\hline $\mathrm{C} 25$ & $(0.0520)$ & $(0.0433)$ & $(0.0451)$ & $(0.0396)$ & $(0.0405)$ \\
\hline $\mathrm{C} 26$ & $(0.0433)$ & $(0.0187)$ & $(0.0172)$ & $(0.0164)$ & $\begin{array}{l}(0.0196) \\
\end{array}$ \\
\hline $\mathrm{C} 31$ & $(0.0619)$ & $(0.0391)$ & $(0.0381)$ & $(0.0335)$ & $(0.0335)$ \\
\hline C32 & $(0.0441)$ & $(0.0408)$ & $(0.0416)$ & $(0.0383)$ & $(0.0416)$ \\
\hline $\mathrm{C} 33$ & $(0.0573)$ & $(0.0272)$ & $(0.0260)$ & $(0.0249)$ & $(0.0217)$ \\
\hline C34 & $(0.0258)$ & $(0.0370)$ & $(0.0365)$ & $(0.0295)$ & $(0.0258)$ \\
\hline C35 & $(0.0260)$ & $(0.0261)$ & $(0.0260)$ & $(0.0261)$ & $\begin{array}{l}(0.0261) \\
\end{array}$ \\
\hline C36 & $(0.0476)$ & $(0.0181)$ & $(0.0310)$ & $(0.0189)$ & $\begin{array}{l}(0.0189) \\
\end{array}$ \\
\hline C41 & $(0.0157)$ & $(0.0119)$ & $(0.0122)$ & $(0.0111)$ & $(0.0111)$ \\
\hline C42 & $(0.0132)$ & $(0.0083)$ & $(0.0086)$ & $(0.0072)$ & $(0.0091)$ \\
\hline $\mathrm{C} 43$ & $(0.1001)$ & $(0.0454)$ & $(0.0472)$ & $(0.0454)$ & $(0.0358)$ \\
\hline C44 & $(0.0536)$ & $(0.0389)$ & $(0.0466)$ & $(0.038)$ & $(0.0406)$ \\
\hline $\mathrm{C} 45$ & $(0.0857)$ & $(0.0388)$ & $(0.0278)$ & $(0.0408)$ & $(0.0307)$ \\
\hline C46 & $(0.0457)$ & $(0.0355)$ & $(0.0346)$ & $(0.0325)$ & $(0.0325)$ \\
\hline C51 & $(0.0749)$ & $(0.0609)$ & $(0.0585)$ & $(0.0585)$ & $(0.0515)$ \\
\hline C52 & $(0.0540)$ & $(0.0234)$ & $(0.0340)$ & $(0.0245)$ & $(0.0205)$ \\
\hline C53 & $(0.1021)$ & $(0.0484)$ & $(0.0444)$ & $(0.0331)$ & $(0.0220)$ \\
\hline C54 & $(0.0820)$ & $(0.0565)$ & $(0.0585)$ & $(0.0444)$ & $(0.0444)$ \\
\hline C61 & $(0.0098)$ & $(0.0053)$ & $(0.0055)$ & $(0.0048)$ & $(0.0053)$ \\
\hline C62 & $(0.0280)$ & $(0.0137)$ & $(0.0152)$ & $(0.0127)$ & $(0.0132)$ \\
\hline C63 & $(0.0328)$ & $(0.0213)$ & $(0.0233)$ & $(0.0233)$ & $(0.0195)$ \\
\hline C64 & $(0.0461)$ & $(0.0374)$ & $(0.0374)$ & $(0.0309)$ & $(0.0338)$ \\
\hline C65 & $(0.0333)$ & $(0.0386)$ & $(0.0333)$ & $(0.0353)$ & $(0.0353)$ \\
\hline C66 & $(0.0396)$ & $(0.0215)$ & $(0.0020)$ & $(0.0215)$ & $(0.0215)$ \\
\hline C67 & $(0.0398)$ & $(0.0064)$ & $(0.0189)$ & $(0.0189)$ & $(0.0064)$ \\
\hline C68 & $(0.0420)$ & $(0.0388)$ & $(0.0397)$ & $(0.0328)$ & $(0.0388)$ \\
\hline $\mathrm{C} 71$ & $(0.0880)$ & $(0.0669)$ & $(0.0812)$ & $(0.0767)$ & $(0.0642)$ \\
\hline $\mathrm{C} 72$ & $(0.0737)$ & $(0.0479)$ & $(0.0524)$ & $(0.0439)$ & $(0.0333)$ \\
\hline $\mathrm{C} 73$ & $(0.0942)$ & $(0.0673)$ & $(0.0673)$ & $(0.0673)$ & $(0.0673)$ \\
\hline$S$ & $(2.1870)$ & $(1.4670)$ & $(1.4660)$ & $(1.4100)$ & $(1.3650)$ \\
\hline K & $(1.0000)$ & $(0.6707)$ & $(0.6703)$ & $(0.6447)$ & $(0.6245)$ \\
\hline $\begin{array}{l}\text { Rank of the } \\
\text { alternatives }\end{array}$ & - & 1 & 2 & 3 & 4 \\
\hline
\end{tabular}


In addition, financial performance and market performance were realized as the two dimensions of business performance. RL's profitability is complex because many factors including technological innovation and the materials' market price are involved in it that could contribute to lowering the recovered materials' quantities and recovery process's price (Bouzon et al. 2016). Although practices of RL still play important role in the competitiveness of some firms, systems of RL are not still regarded very important than forward production-distribution SC in terms of potential revenues, asset valuation, and costs. In other terms, because of many reasons, some firms consider RL as SC's undervalued part (Abdulrahman et al. 2014).

By standard product life cycle curve it is typically shown that growth stage holds the highest profits. Manufacturers must reinvest some of those profits in promotional and marketing activities during growth stage to make sure that a product has as long a life as possible, reduce competition threat and guarantee continual growth. Most of the companies invest heavily in the development of new product to pave the way for the continual growth of their product, because they understand that the products they sell all have a limited lifespan. The stage of growth is typically characterized by a strong growth in profits and sales, and because the company can start to benefit from economies of scale in production, then the profit margins and profit's overall amount will increase. Then, businesses are able to invest more money in the promotional activity to maximize the growth stage's potential. On the other hand, manufacturing successfully is not only limited to understanding this life cycle, it is management of products throughout their lifetime, applying the appropriate strategies of marketing, sales, and resources depending on the stage of the cycle, which products are in.

Waste materials and returned products' involved high level of uncertainty causes RL to be extremely intensive to information (Cheng, Lee 2010). Returns of product is the part of business and in order to be a successful organization, managing them efficiently is very crucial. This study will help managers to make sure about the sustainable development even at the time of outsourcing the functions of RL. Proposed study's chosen sub-attributes and attributes will guide the decision makers to analyse and visualize these sub-attributes and attributes' influence on decisions of outsourcing. By this, consultants and management may be provided by supports for making strategic decisions like business partner selection in competitive business environment, logistics firm selection, and new plant site selection. Although among environment, economic, and remanufacturing perspectives, remanufacturing is an alternative, which is more viable, firms prefer recycling over remanufacturing in the current market conditions because of lower cost model, competitiveness, remanufacturing capability of the firm and attitude of customer (Agrawal et al. 2016a). New products' sales and price volume may be influenced through remanufactured products' sale in the market. Therefore, in comparison to remanufacturing, firms prefer recycling.
RL related financial transactions can be very complex. One cannot assess RL as a mutually independent activity. Incorporating all related financial and business connections to RL to compare business practices is very crucial. Best-in-class companies must optimize their operations of RL from perspectives of tax and operation. It is believed that combining both aspects leads to maximum financial results. Capturing all relevant information by the systems is even more essential for managers. However, it is revealed by this study that information systems, in respect of the reverse chain, hold considerable gaps for tax and financial reporting. In addition, many operation managers who were interviewed were not sure about how operations' financial results could be decisively influenced through tax. In general, our study identifies a marked lack of specialist tax knowledge in respect of the reverse chain. The ability to focus on core competencies is improved and financial risks are limited by outsourcing. These are research and development, marketing and sales for many companies. ICT RL' major difficulties are in the collection and its costs involved in this process, which often leads to derail of the process. Companies of electronics recycling and industry associations do not have actual data of returned materials' quantities, which makes it difficult to analyse the cost of materials, their efficiency, and the amount these materials are reused. Defining aspects of geography and scope are needed in configuration of recovery network. The designation, which intermediaries/participants should be included, is needed in defining the scope. Recovery channels are very rarely including direct channels fully managed by manufacturer. More often companies create multilevel indirect channels through recycling companies, core brokers, retailers, and distributers.

\section{Conclusions}

Our goal in this article providing a framework is outlined for 3PRL's evaluation and then, a method is developed in fuzzy environment as we have not come across any application of this technique in assessment of 3rdPRLPs. The core goal of current research is developing a framework by which it evaluates 3rdPRLP MCDM based on FARAS. The paper presents a newly-developed FARAS method to solve different problems in technology, transport construction, and economics development. In this research trapezoidal fuzzy numbers were used which can encompass more uncertainty than the triangular fuzzy number. Thirty-seven criteria were identified which are classified into seven main criteria. The main criteria were ranked as follows: product lifecycle position C1, RL process function $\mathrm{C} 2$, organizational performance $\mathrm{C} 3$, organizational role of RL C4, IT system and communication C5, general company consideration C6, geographical location C7. Market coverage, destination, financial considerations, integrated system, reclaim, efficiency and quality, and growth are each group's dominant sub-criteria. Based on the results obtained from our findings the attention to organizational performance and process function are the important fac- 
tors that helps the logistics managers to better understand the key attributes' complex relationships in the environment of decision-making. In addition, the current research helps the logistics managers to better understand the key attributes' complex relationships in the environment of decision-making

Based on different attributes of disposition, this study utilizes the FARAS for the selection of best alternative of disposition. Through getting help with the experts and based on review of past literature, attributes are selected in this study. These attributes are selected from RL operational, environmental, and economic aspects. It is not easy to select a proper provider, which fits the outsourcing company's needs. 3PL providers, by which best practices are displays, give information to managers. Therefore, managers may gain more efficient firms' experiences. Consequently, firms are benefited from collaboration among the 3PL providers. Alternative scenarios and sub-attributes and attributes are based on one firm, which is one of limitations of this study. On the other hand, one can easily acclimatize methodology to different scenarios and can consider different kind of qualitative and quantitative attributes depending on the need of business. Forming only twelve experts in one group is another limitation of this study. In future studies, there may be use of experts in a larger group and more case studies may be developed for the generalization of findings and results. Further, in real life business environment it is very difficult to find suitable criteria for the selection and evaluation of outsourcing partner. Overall performance of RL may be improved by the findings of this study. For both researchers and practitioners identifying systematic approaches and main criteria can help to understand 3rdPRLP-selection related issues.

\section{References}

Akhavan, P.; Barak, S.; Maghsoudlou, H.; Antuchevičienè, J. 2015. FQSPM-SWOT for strategic alliance planning and partner selection; case study in a holding car manufacturer company, Technological and Economic Development of Economy 21(2): 165-185. http://doi.org/10.3846/20294913.2014.965240

Abdulrahman, M. D.; Gunasekaran, A.; Subramanian, N. 2014. Critical barriers in implementing reverse logistics in the Chinese manufacturing sectors, International Journal of Production Economics 147: 460-471.

http://doi.org/10.1016/j.ijpe.2012.08.003

Agrawal, S.; Singh, R. K.; Murtaza, Q. 2016a. Disposition decisions in reverse logistics: Graph theory and matrix approach, Journal of Cleaner Production 137: 93-104. http://doi.org/10.1016/j.jclepro.2016.07.045

Agrawal, S.; Singh, R. K.; Murtaza, Q. 2016b. Outsourcing decisions in reverse logistics: Sustainable balanced scorecard and graph theoretic approach, Resources, Conservation and Recycling 108: 41-53.

http://doi.org/10.1016/j.resconrec.2016.01.004

Aguezzoul, A. 2007. The third party logistics selection: a review of literature, in International Logistics and Supply Chain Congress 2007, 8-9 November 2007, Istanbul, Turkey, 1-7.
Aguezzoul, A. 2014. Third-party logistics selection problem: a literature review on criteria and methods, Omega 49: 69-78. http://doi.org/10.1016/j.omega.2014.05.009

Amini, M. M.; Retzlaff-Roberts, D.; Bienstock, C. C. 2005. Designing a reverse logistics operation for short cycle time repair services, International Journal of Production Economics 96(3): 367-380. http://doi.org/10.1016/j.ijpe.2004.05.010

Azadi, M.; Saen, R. F. 2011. A new chance-constrained data envelopment analysis for selecting third-party reverse logistics providers in the existence of dual-role factors, Expert Systems with Applications 38(10): 12231-12236.

http://doi.org/10.1016/j.eswa.2011.04.001

Bai, C.; Sarkis, J. 2013. Flexibility in reverse logistics: a framework and evaluation approach, Journal of Cleaner Production 47: 306-318. http://doi.org/10.1016/j.jclepro.2013.01.005

Baležentis, A., Baležentis, T., Misiūnas, A. 2012. An integrated assessment of Lithuanian economic sectors based on financial ratios and fuzzy MCDM methods, Technological and Economic Development of Economy 18(1): 34-53.

https://doi.org/10.3846/20294913.2012.656151

Bazan, E.; Jaber, M. Y.; Zanoni, S. 2016. A review of mathematical inventory models for reverse logistics and the future of its modeling: an environmental perspective, Applied Mathematical Modelling 40(5-6): 4151-4178. http://doi.org/10.1016/j.apm.2015.11.027

Bei, W.; Linyan, S. 2005. A review of reverse logistics, Applied Sciences (APPS) 7: 16-29.

Bellman, R. E.; Zadeh, L. A. 1970. Decision-making in a fuzzy environment, Management Science 17(4): B-141-B-164. https://doi.org/10.1287/mnsc.17.4.B141

Blumberg, D. F. 1999. Strategic examination of reverse logistics \& repair service requirements, needs, market size, and opportunities, Journal of Business Logistics 20(2): 141-160.

Bottani, E.; Rizzi, A. 2006. A fuzzy TOPSIS methodology to support outsourcing of logistics services, Supply Chain Management 11(4): 294-308. http://doi.org/10.1108/13598540610671743

Bouzon, M.; Govindan, K.; Rodriguez, C. M. T. 2015. Reducing the extraction of minerals: reverse logistics in the machinery manufacturing industry sector in Brazil using ISM approach, Resources Policy 46: 27-36.

http://doi.org/10.1016/j.resourpol.2015.02.001

Bouzon, M.; Govindan, K.; Rodriguez, C. M. T.; Campos, L. M. S. 2016. Identification and analysis of reverse logistics barriers using fuzzy Delphi method and AHP, Resources, Conservation and Recycling 108: 182-197.

http://doi.org/10.1016/j.resconrec.2015.05.021

Büyüközkan, G.; Feyzioğlu, O.; Nebol, E. 2008. Selection of the strategic alliance partner in logistics value chain, International Journal of Production Economics 113(1): 148-158. http://doi.org/10.1016/j.ijpe.2007.01.016

Büyüközkan, G.; Göçer, F. 2018. An extension of ARAS methodology under interval valued intuitionistic fuzzy environment for digital supply chain, Applied Soft Computing 69: 634-654. http://doi.org/10.1016/j.asoc.2018.04.040

Carter, C. R.; Ellram, L. M. 1998. Reverse logistics: a review of the literature and framework for future investigation, Journal of Business Logistics 19(1): 85-102.

Cheng, J.-H.; Chen, S.-S.; Chuang, Y.-W. 2008. An application of fuzzy Delphi and fuzzy AHP for multi-criteria evaluation model of fourth party logistics, WSEAS Transactions on Systems 7(5): 466-478. Available from Internet: http://www. wseas.us/e-library/transactions/systems/2008/26-120.pdf 
Cheng, Y.-H.; Lee, F. 2010. Outsourcing reverse logistics of high-tech manufacturing firms by using a systematic decision-making approach: TFT-LCD sector in Taiwan, Industrial Marketing Management 39(7): 1111-1119.

http://doi.org/10.1016/j.indmarman.2009.10.004

Dadelo, S.; Turskis, Z.; Zavadskas, E. K.; Dadelienè, R. 2012. Multiple criteria assessment of elite security personal on the basis of ARAS and expert methods, Economic Computation and Economic Cybernetics Studies and Research 46(4): 65-87.

Dahooie, J. H.; Zavadskas, E. K.; Abolhasani, M.; Vanaki, A.; Turskis, Z. 2018. A novel approach for evaluation of projects using an interval-valued fuzzy additive ratio assessment (ARAS) method: a case study of oil and gas well drilling projects, Symmetry 10(2): 45. http://doi.org/10.3390/sym10020045

De Almeida, A. T. 2007. Multicriteria decision model for outsourcing contracts selection based on utility function and ELECTRE method, Computers \& Operations Research 34(12): 3569-3574. http://doi.org/10.1016/j.cor.2006.01.003

Ecer, F. 2018. An integrated auzzy AHP and ARAS model to evaluate mobile banking services, Technological and Economic Development of Economy 24(2): 670-695.

http://doi.org/10.3846/20294913.2016.1255275

Efendigil, T.; Önüt, S.; Kongar, E. 2008. A holistic approach for selecting a third-party reverse logistics provider in the presence of vagueness, Computers \& Industrial Engineering 54(2): 269-287. http://doi.org/10.1016/j.cie.2007.07.009

Falsini, D.; Fondi, F.; Schiraldi, M. M. 2012. A logistics provider evaluation and selection methodology based on AHP, DEA and linear programming integration, International Journal of Production Research 50(17): 4822-4829.

http://doi.org/10.1080/00207543.2012.657969

Fernandez, I.; Kekale, T. 2008. Better models with Delphi and analytic hierarchy process approaches: the case of reverse logistics, International Journal of Logistics Systems and Management 4(3): 282-296.

http://doi.org/10.1504/IJLSM.2008.017477

Fisk, G.; Chandran, R. 1975. How to trace and recall products, Harvard Business Review 53(6): 90-96.

Fleischmann, M.; Bloemhof-Ruwaard, J. M.; Dekker, R.; Van Der Laan, E.; Van Nunen, J. A. E. E.; Van Wassenhove, L. N. 1997. Quantitative models for reverse logistics: a review, European Journal of Operational Research 103(1): 1-17. http://doi.org/10.1016/S0377-2217(97)00230-0

Ghadikolaei, A. S.; Esbouei, S. K.; Antuchevičienè, J. 2014. Applying fuzzy MCDM for financial performance evaluation of Iranian companies, Technological and Economic Development of Economy 20(2): 274-291. http://doi.org/10.3846/20294913.2014.913274

Giuntini, R.; Andel, T. 1995a. Advance with reverse logistics, Transportation and Distribution 36(2): 73-77.

Giuntini, R.; Andel, T. 1995b. Master the six R's of reverse logistics, Transportation and Distribution 36(3): 93-98.

Giuntini, R.; Andel, T. 1995c. Reverse logistics role models, Transportation and Distribution 36(4): 97-98.

Govindan, K.; Paam, P.; Abtahi, A.-R. 2016. A fuzzy multi-objective optimization model for sustainable reverse logistics network design, Ecological Indicators 67: 753-768. http://doi.org/10.1016/j.ecolind.2016.03.017

Govindan, K.; Popiuc, M. N. 2014. Reverse supply chain coordination by revenue sharing contract: A case for the personal computers industry, European Journal of Operational Research 233(2): 326-336. http://doi.org/10.1016/j.ejor.2013.03.023

Govindan, K.; Soleimani, H. 2017. A review of reverse logistics and closed-loop supply chains: a Journal of Cleaner Produc- tion focus, Journal of Cleaner Production 142: 371-384.

http://doi.org/10.1016/j.jclepro.2016.03.126

Göl, H.; Çatay, B. 2007. Third-party logistics provider selection: insights from a Turkish automotive company, Supply Chain Management 12(6): 379-384.

http://doi.org/10.1108/13598540710826290

Guarnieri, P.; Sobreiro, V. A.; Nagano, M. S.; Marques Serrano, A. L. 2015. The challenge of selecting and evaluating third-party reverse logistics providers in a multicriteria perspective: a Brazilian case, Journal of Cleaner Production 96: 209-219. http://doi.org/10.1016/j.jclepro.2014.05.040

Guide, V. D. R.; Harrison, T. P.; Van Wassenhove, L. N. 2003. The challenge of closed-loop supply chains, Interfaces 33(6): 3-6. http://doi.org/10.1287/inte.33.6.3.25182

Haji Vahabzadeh, A.; Asiaei, A.; Zailani, S. 2015. Reprint of "Green decision-making model in reverse logistics using FUZZY-VIKOR method”, Resources, Conservation and Recycling 104: 334-347.

http://doi.org/10.1016/j.resconrec.2015.10.028

Jayaraman, V.; Patterson, R. A.; Rolland, E. 2003. The design of reverse distribution networks: Models and solution procedures, European Journal of Operational Research 150(1): 128-149. http://doi.org/10.1016/S0377-2217(02)00497-6

Kannan, G. 2009. Fuzzy approach for the selection of third party reverse logistics provider, Asia Pacific Journal of Marketing and Logistics 21(3): 397-416.

http://doi.org/10.1108/13555850910973865

Kannan, G.; Pokharel, S.; Kumar, P. S. 2009. A hybrid approach using ISM and fuzzy TOPSIS for the selection of reverse logistics provider, Resources, Conservation and Recycling 54(1): 28-36. http://doi.org/10.1016/j.resconrec.2009.06.004

Kaufmann, A.; Gupta, M. M. 1991. Introduction to Fuzzy Arithmetic: Theory and Applications. Van Nostrand Reinhold. $361 \mathrm{p}$.

Keršulienè, V.; Turskis, Z. 2014. A hybrid linguistic fuzzy multiple criteria group selection of a chief accounting officer, Journal of Business Economics and Management 15(2): 232-252. https://doi.org/10.3846/16111699.2014.903201

Keršuliene, V.; Turskis, Z. 2011. Integrated fuzzy multiple criteria decision making model for architect selection, Technological and Economic Development of Economy 17(4): 645-666.

Khodaverdi, R.; Hashemi, S. H. 2015. A grey-based decisionmaking approach for selecting a reverse logistics provider in a closed loop supply chain, International Journal of Management and Decision Making 14(1): 32-43.

https://doi.org/10.1504/IJMDM.2015.067376

Kleindorfer, P. R.; Partovi, F. Y. 1990. Integrating manufacturing strategy and technology choice, European Journal of Operational Research 47(2): 214-224.

http://doi.org/10.1016/0377-2217(90)90280-O

Kutut, V.; Zavadskas, E. K.; Lazauskas, M. 2013. Assessment of priority options for preservation of historic city centre buildings using MCDM (ARAS), Procedia Engineering 57: 657661. https://doi.org/10.1016/j.proeng.2013.04.083

Liu, H.-C.; Liu, L.; Liu, N.; Mao, L.-X. 2012. Risk evaluation in failure mode and effects analysis with extended VIKOR method under fuzzy environment, Expert Systems with Applications 39(17): 12926-12934.

http://doi.org/10.1016/j.eswa.2012.05.031

Meade, L.; Sarkis, J. 2002. A conceptual model for selecting and evaluating third-party reverse logistics providers, Supply Chain Management 7(5): 283-295.

http://doi.org/10.1108/13598540210447728 
Menon, M. K.; McGinnis, M. A.; Ackerman, K. B. 1998. Selection criteria for providers of third-party logistics services: an exploratory study, Journal of Business Logistics 19(1): 121-137.

Min, H.; Ko, H.-J. 2008. The dynamic design of a reverse logistics network from the perspective of third-party logistics service providers, International Journal of Production Economics 113(1): 176-192. http://doi.org/10.1016/j.ijpe.2007.01.017

Murphy, P. 1986. A preliminary study of transportation and warehousing aspects of reverse distribution, Transportation Journal 25(4): 12-21.

Nguyen, H.-T.; Dawal, S. Z.; Nukman, Y.; Rifai, A. P.; Aoyama, H. 2016. An integrated MCDM model for conveyor equipment evaluation and selection in an FMC based on a fuzzy AHP and fuzzy ARAS in the presence of vagueness, PLoS ONE 11(4): e0153222. http://doi.org/10.1371/journal.pone.0153222

Pati, R. K.; Vrat, P.; Kumar, P. 2008. A goal programming model for paper recycling system, Omega 36(3): 405-417. http://doi.org/10.1016/j.omega.2006.04.014

Perçin, S.; Min, H. 2013. A hybrid quality function deployment and fuzzy decision-making methodology for the optimal selection of third-party logistics service providers, International Journal of Logistics Research and Applications: a Leading Journal of Supply Chain Management 16(5): 380-397. http://doi.org/10.1080/13675567.2013.815696

Prakash, C.; Barua, M. K. 2016a. A combined MCDM approach for evaluation and selection of third-party reverse logistics partner for Indian electronics industry, Sustainable Production and Consumption 7: 66-78.

http://doi.org/10.1016/j.spc.2016.04.001

Prakash, C.; Barua, M. K. 2016b. An analysis of integrated robust hybrid model for third-party reverse logistics partner selection under fuzzy environment, Resources, Conservation and Recycling 108: 63-81. http://doi.org/10.1016/j.resconrec.2015.12.011

Rajesh, R.; Pugazhendhi, S.; Ganesh, K. 2009. An analytic model for selection of and allocation among third party logistics service providers, International Journal of Enterprise Network Management 3(3): 268-288.

http://doi.org/10.1504/IJENM.2009.032398

Ravi, V.; Shankar, R.; Tiwari, M. K. 2005. Analyzing alternatives in reverse logistics for end-of-life computers: ANP and balanced scorecard approach, Computers \& Industrial Engineering 48(2): 327-356. http://doi.org/10.1016/j.cie.2005.01.017

Rogers, D. S.; Tibben-Lembke, R. 2001. An examination of reverse logistics practices, Journal of Business Logistics 22(2): 129-148. http://doi.org/10.1002/j.2158-1592.2001.tb00007.x

Rostamzadeh, R.; Esmaeili, A.; Shahriyari Nia, A.; Šaparauskas, J.; Keshavarz Ghorabaee, M. 2017. A fuzzy ARAS method for supply chain management performance measurement in SMEs under uncertainty, Transformations in Business \& Economics 16(2A): 319-348.

Rostamzadeh, R.; Ismail, K.; Khajeh Noubar, H. B. 2014a. An application of a hybrid MCDM method for the evaluation of entrepreneurial intensity among the SMEs: a case study, The Scientific World Journal 2014: 703650. http://doi.org/10.1155/2014/703650

Rostamzadeh, R.; Ismail, K.; Zavadskas, E. K. 2014b. Multi criteria decision making for assisting business angels in investments, Technological and Economic Development of Economy 20(4): 696-720. http://doi.org/10.3846/20294913.2014.984364

Sarkis, J. 1998. Evaluating environmentally conscious business practices, European Journal of Operational Research 107(1): 159-174. http://doi.org/10.1016/S0377-2217(97)00160-4
Senthil, S.; Murugananthan, K.; Ramesh, A. 2018. Analysis and prioritisation of risks in a reverse logistics network using hybrid multi-criteria decision making methods, Journal of Cleaner Production 179: 716-730.

http://doi.org/10.1016/j.jclepro.2017.12.095

Senthil, S.; Srirangacharyulu, B.; Ramesh, A. 2014. A robust hybrid multi-criteria decision making methodology for contractor evaluation and selection in third-party reverse logistics, Expert Systems with Applications 41(1): 50-58. http://doi.org/10.1016/j.eswa.2013.07.010

Shariati, S.; Yazdani-Chamzini, A.; Salsani, A.; Tamošaitienė, J. 2014. Proposing a new model for waste dump site selection: case study of Ayerma phosphate mine, Inžinerine Ekonomika - Engineering Economics 25(4): 410-419.

https://doi.org/10.5755/j01.ee.25.4.6262

Shemshadi, A.; Shirazi, H.; Toreihi, M.; Tarokh, M. J. 2011. A fuzzy VIKOR method for supplier selection based on entropy measure for objective weighting, Expert Systems with Applications 38(10): 12160-12167. http://doi.org/10.1016/j.eswa.2011.03.027

Sink, H. L.; Langley, C. J. 1997. A managerial framework for the acquisition of third-party logistics services, Journal of Business Logistics 18(2): 163-189.

Sink, H. L.; Langley, C. J.; Gibson, B. J. 1996. Buyer observations of the US third-party logistics market, International Journal of Physical Distribution \& Logistics Management 26(3): 38-46. https://doi.org/10.1108/09600039610115009

So, S.-H.; Kim, J.; Cheong, K.; Cho, G. 2006. Evaluating the service quality of third-party logistics service providers using the analytic hierarchy process, Journal of Information Systems and Technology Management 3(3): 261-270. http://doi.org/10.4301/S1807-17752006000300001

Stanujkic, D. 2015. Extension of the ARAS method for decisionmaking problems with interval-valued triangular fuzzy numbers, Informatica 26(2): 335-355. https://doi.org/10.15388/Informatica.2015.51

Stock, J.; Speh, T.; Shear, H. 2002. Many happy (product) returns, Harvard Business Review 7. Available from Internet: https://hbr.org/2002/07/many-happy-product-returns

Subramoniam, R.; Huisingh, D.; Chinnam, R. B.; Subramoniam, S. 2013. Remanufacturing decision-making framework (RDMF): research validation using the analytical hierarchical process, Journal of Cleaner Production 40: 212-220. http://doi.org/10.1016/j.jclepro.2011.09.004

Tate, K. 1996. The elements of a successful logistics partnership, International Journal of Physical Distribution \& Logistics Management 26(3): 7-13. https://doi.org/10.1108/09600039610115045

Tavana, M.; Zareinejad, M.; Di Caprio, D.; Kaviani, M. A. 2016. An integrated intuitionistic fuzzy AHP and SWOT method for outsourcing reverse logistics, Applied Soft Computing 40: 544-557. http://doi.org/10.1016/j.asoc.2015.12.005

Trochu, J.; Chaabane, A.; Ouhimmou, M. 2018. Reverse logistics network redesign under uncertainty for wood waste in the CRD industry, Resources, Conservation and Recycling: 32-47. http://doi.org/10.1016/j.resconrec.2017.09.011

Tupenaite, L.; Zavadskas, E. K.; Kaklauskas, A.; Turskis, Z.; Seniut, M. 2010. Multiple criteria assessment of alternatives for built and human environment renovation, Journal of Civil Engineering and Management 16(2): 257-266.

http://doi.org/10.3846/jcem.2010.30

Turskis, Z.; Lazauskas, M.; Zavadskas, E. K. 2012. Fuzzy multiple criteria assessment of construction site alternatives for non- 
hazardous waste incineration plant in Vilnius city, applying ARAS-F and AHP methods, Journal of Environmental Engineering and Landscape Management 20(2): 110-120. https://doi.org/10.3846/16486897.2011.645827

Turskis, Z.; Zavadskas, E. K. 2010. A new fuzzy additive ratio assessment method (ARAS-F). Case study: the analysis of fuzzy multiple criteria in order to select the logistic centers location, Transport 25(4): 423-432.

https://doi.org/10.3846/transport.2010.52

Yang, M. G.; Hong, P.; Modi, S. B. 2011. Impact of lean manufacturing and environmental management on business performance: an empirical study of manufacturing firms, International Journal of Production Economics 129(2): 251-261. http://doi.org/10.1016/j.ijpe.2010.10.017

Zadeh, L. A. 1965. Fuzzy sets, Information and Control 8(3): 338-353. https://doi.org/10.1016/S0019-9958(65)90241-X

Zamani, M.; Rabbani, A.; Yazdani-Chamzini, A.; Turskis, Z. 2014. An integrated model for extending brand based on fuzzy ARAS and ANP methods, Journal of Business Economics and Management 15(3): 403-423. http://doi.org/10.3846/16111699.2014.923929

Zavadskas, E. K., Turskis. Z. 2010. A new additive ratio assessment (ARAS) method in multicriteria decision-making, Technological and Economic Development of Economy 16(2):159172. https://doi.org/10.3846/tede.2010.10

Zavadskas, E. K.; Turskis, Z.; Vilutienè, T.; Lepkova, N. 2017. Integrated group fuzzy multi-criteria model: case of facilities management strategy selection, Expert Systems with Applications 82: 317-331. https://doi.org/10.1016/j.eswa.2017.03.072

Zhang, Y.; Feng, Y. 2007. A selection approach of reverse logistics provider based on fuzzy AHP, in Fourth International Conference on Fuzzy Systems and Knowledge Discovery (FSKD 2007), 24-27 August 2007, Haikou, China, 479-482. http://doi.org/10.1109/FSKD.2007.119

Zimmermann, H.-J. 1987. Fuzzy Sets, Decision Making, and Expert Systems. Springer Science + Business Media, LLC. 336 p. https://doi.org/10.1007/978-94-009-3249-4

Zimmermann, H.-J. 1991. Fuzzy Set Theory and Its Applications. Springer Science + Business Media, LLC. 399 p.

https://doi.org/10.1007/978-94-015-7949-0 